\title{
İslami İktisat Çerçevesinde Günler: Karma Yöntem Araştırması
}

\author{
Abdullah Talha GENÇ* \\ Sakarya Üniversitesi \\ Ali Can YENİCE** \\ Sakarya Üniversitesi \\ Zeyneb Hafsa ORHAN*** \\ İstanbul Sabahattin Zaim Üniversitesi
}

Öz

Bu çalışmada, banka harici finansal yapılardan günler (para-altın, döviz vb.) ele alınmakta ve toplumsal ilişkilerin bir parçası olan bu uygulamaların, İslam iktisadının hedefleriyle örtüşmesi bakımından alternatif bir çözüm yolu olup olmadığı araştırılmaktadır. Araştırma çerçevesinde sosyal, iktisadi ve fıkhi yönleri olan günlerin işleyişlerini ve katılımcıların özelliklerini keşfetmek ve günlere katılımı etkileyen faktörleri tespit etmek amacıyla karma yöntem tercih edilmiștir. Gün olgusunun enformel yapıya sahip olması nedeniyle çalışmada keşfedici ardışık desen kullanılmıştır. Bu desende ele alınan olguyu keşfetmek amacıyla ilk olarak nitel yöntem ikinci olarak ise nicel yöntem kullanılır. Çalışmanın nitel kısmında gün olgusuna yönelik güven, sosyalleșme, dayanışma, dini hassasiyet, tasarruf, yatırım, tüketim ve finansal piyasalara erişememe olmak üzere sekiz tema keșfedilmiştir. Nicel kısımda ise gerçekleștirilen açımlayıcı faktör analizi sonucunda formel finansal piyasalardan faydalanamama, manevi boyut, sosyalleşme, aile bütçesine katkl, temel tüketim, faizden kaçınma, tasarrufa zorlama ve yatırım faktörlerinin güne katılmayı etkilediği tespit edilmiștir. Daha sonra bu faktörlerin cinsiyet, eğitim düzeyi, meslek ve hane halkı aylık gelir düzeyine göre anlamlı farklılıkların olup olmadığı test edilmiştir. Gün olgusunun karma yöntem ile araștırılması ve manevi boyutun faktör olarak tespit edilmesi bu çalıșmanın özgün yönlerini oluşturmaktadır. Bu doğrultuda sosyal, iktisadi ve fıkhi boyutları barındıran günlerin banka dişı İslami finansal bir fenomen olduğu ileri sürülmektedir.

\section{Anahtar Kelimeler}

Íslami İktisat, Banka Harici Finansal Yapılar, Günler

* Arş. Gör., Sakarya Üniversitesi İslam Ekonomisi ve Finansı Uygulama ve Araştırma Merkezi (ISEFAM), abdullahgenc@sakarya.edu.tr ORCID 0000-0001-8811-8609

** Arş. Gör., Sakarya Üniversitesi İslam Ekonomisi ve Finansı Uygulama ve Araştırma Merkezi (ISEFAM) ayenice@sakarya.edu.tr ORCID 0000-0002-1869-6814

*** Doç. Dr., İstanbul Sabahattin Zaim Üniversitesi İșletme ve Yönetim Bilimleri Fakültesi, hafsa. orhan@izu.edu.tr ORCID 0000-0002-7515-910X 


\title{
Informal Rotating Savings and Credit Associations From The Perspective of Islamic Economics: A Mixed-Method Study
}

\begin{abstract}
In this study, güns (singular: gün) from non-bank financial structures (money-gold, foreign exchange, etc.) are discussed and whether these practices, which are a part of social relations, are an alternative solution in terms of coinciding with the goals of Islamic economics. In the framework of the research, a mixed method was preferred in order to discover the functioning of the güns with social, economic, and fiqh aspects and the characteristics of the participants and to determine the factors affecting the participation in the güns. Due to the informal type of the gün phenomenon, exploratory sequential design was used in the study. In this design, firstly, qualitative method and secondly, quantitative method is used in order to discover the phenomenon discussed. In the qualitative part of the study, eight themes were discovered for the phenomenon of the gün: trust, socialization, solidarity, religious sensitivity, saving, investment, consumption and inability to access financial markets. As a result of the exploratory factor analysis carried out in the quantitative part, it was determined that the inability to benefit from formal financial markets, spiritual dimension, socialization, contribution to the family budget, basic consumption, avoidance of interest, forcing savings and investment factors affect participation in the gün. Afterwards, it was tested whether there are significant differences in these factors according to gender, education level, profession and household monthly income level. Investigating the phenomenon of güns with mixed method and determining the spiritual dimension as a factor constitute the original aspects of this study. Accordingly, it is claimed that the güns with social, economic and fiqh dimensions are an Islamic financial phenomenon outside the bank.
\end{abstract}

\section{Keywords}

Islamic Economics, Non-Bank Financial Structures, Guns

\section{Extended Abstract}

Rosca, which is known in Turkey as "gün", is an informal organization that is embedded in social relations and can meet the needs of cooperation, solidarity, socialization, and small financial needs (Eroğlu, 2010; Ardener, 1964; Geertz, 1962).

Members of güns maintain a social relationship by contributing to each other in cash or material in the amount and order they determine. Although the size of the financial amount obtained through the güns cannot be determined precisely, it is known that they form a widespread network within the society (Eroğlu, 2010). There is an unwritten or written control mechanism of the güns.

The gün organization provides a wide range of social support to the members. The participants come together to share their troubles and happiness, to meet with their family, relatives, neighbors, and thus they both relax psychologically and have the opportunity to socialize (Büyükokutan, 2012; Karayiğit, 2015). This organization has economically advantageous and disadvantageous aspects. The most important advantage is that it forces its members to save. In addition, the organization also has functions in terms of consumption, insurance, and investment with the money or gold they receive from the güns (Aliero,2014). It meets the basic needs of households for consumption purposes. In terms of insurance, it meets the urgent cash needs of the members. It also allows investing in buying a house, car or offering new capital investment for small entrepreneurs (Ardener, 1964; Aredo, 2004; Ullah, Naimi ve Yusoff, 2016). The organization is easily accessible and implemented among people who know each other, saves the participants from contract costs (Kirton, 1996). It also 
provides an economic opportunity to the organization's participants in terms of providing financing to those who cannot benefit from formal financial markets (Eroğlu, 2010). However, the main disadvantage of the güns is the failure of the participants to fulfill their payment responsibilities. The embarrassment or disrepute caused by not fulfilling the payment responsibility prevents people from joining the organization. In this direction, it is easier for people with regular income to participate in this organization (Eroğlu, 2010). Another disadvantage of the güns' is that the time of the money received from the gün and the time planned to be spent do not match (Kirton, 1996).

In terms of fiqh, the gün organization is implemented based on the qard contract (Aliero, 2014; Duman, 2018; Kaya, 2019). In this context, the most fundamental issue of this organization is not to incur interest. Qard-ul hasen is an exception to the cash exchange of money of the same type (Apaydın, 2001, s.522). Another issue in terms of fiqh is the binding of maturity. This issue is resolved because the organization functions where individuals can join and leave voluntarily without any coercion (Duman, 2018).

In this study, a mixed-method was preferred to explore the functions of money-gold and foreign exchange of the organization and the characteristics of the participants and determine the factors affecting the participation in these organizations. The exploratory sequential design, one of the mixed-method designs, was used in the study. In the qualitative part of the study, interview, which is a qualitative analysis method, was used in order to discover the functioning of the gün phenomenon, the characteristics of the people participating in the gün, the reasons for participating in the gün, and the fiqh, economic and social aspects of the gün from the perspective of the participants. By evaluating the information obtained from the qualitative data and making use of the literature, the themes affecting the participation in the güns were determined, and these themes were presented to a broader audience through a questionnaire, which is a quantitative analysis method.

In the qualitative part of this study, interviews were conducted with 9 participants who had experience with such organizations. Participants consist of two housewives, three merchants, two civil servants, and two workers. In the quantitative portion of the study, the questionnaire which is used by the study of Kahyaoğlu et al. (2016) is requested and is developed based on the qualitative data. First, a pilot study was conducted with 105 participants in order to identify the ambiguities and questions of participants about the questionnaire. Necessary adjustments were made, and the questionnaire was finalized. The final version of the questionnaire was applied to 420 participants, and 349 of them were included in the analysis.

In the light of the data obtained from the qualitative part of the study, eight themes for the gün organization were discovered: trust, socialization, solidarity, religious sensitivity, savings, investment, consumption, and inaccessibility to financial markets. In particular, the theme of religious sensitivity consists of sub-themes of interest sensitivity, maintaining kinship, and human rights. At this point, the importance of religious sensitivity these güns' was discovered.

As a result of the exploratory factor analysis applied in the quantitative part of the study, the questions were grouped under eight factors, and their total variance was 76.857 . 
The Cronbach Alpha ratio, which shows the reliability of the scale, is 0.912 . When the items under the factors are examined, the inability to benefit from the traditional financial markets (0.910), the spiritual dimension (0.878), socialization (0.903), contribution to the family budget (0.862), essential consumption (0.777), interest avoidance (0.895), forced savings (0.789) and investment (0.915) factors were determined.

As a result, one of the unique aspects of this study is that the themes of trust, solidarity, and religious sensitivity discovered in the qualitative part come together in the quantitative part, under the spiritual dimension factor. The depth of the spiritual dimension of the gün phenomenon is demonstrated by the fact that individuals try to protect the "rights" of the people they participate in the organization, pay attention to "write off each other's debts " with them, and provide individuals with opportunities for family and relative relationships.

Savings-based interest-free financing institutions, common in Turkey, use the expression "just like gold güns" when explaining their activities because they are a practice known by society. Saving-based interest-free financing institutions are a commercially developed and systematized type of gün organizations. In this respect, it is necessary to say that such organizations have a significant social financing potential. However, the limited number of studies on these organizations in the Islamic finance literature indicates that more studies are needed on the gün phenomenon. In this direction, to establish financial institutions with strong ties to individuals and social relations, it is necessary to determine the characteristics of the structures that the society has experienced for many years and know the benefits and costs. In the light of the information which is obtained from this study, it is possible to say that the gün phenomenon is a modern social finance instrument, has a vital role in the economic development of society. The güns' are considered in non-bank structures throughout the study, reminding the social embeddedness of economics to perform the financing function without ignoring its social aspect. 


\section{Giriş}

Modern anlamda İslam iktisadının ortaya çıkışı yirminci yüzyılın ikinci çeyreğine denk düşmektedir. Bağımsızlıklarını henüz yeni kazanmış Müslüman ülkelerin gündeminde, dini değerlerini muhafaza ederek idari, iktisadi ve sosyal meselelere dair yapılanmalarını nasıl gerçekleştirecekleri sorusu bulunmaktaydı. Başta Hindistan'dan ayrılan Pakistan olmak üzere birçok İslam ülkesi bu meselelere dair kaygılar taşımaktaydı. Karşılarında kapitalist ve sosyalist sistemler bulunmakta ve bunlar, Müslümanların düşünce dünyalarıyla örtüşmemekteydi. 1976 yılında İslam Konferansı Teşkilatı ${ }^{1}$ tarafından ilki gerçekleştirilen "Uluslararası İslam İktisadı Konferansı" devletlerarası dayanışmanın geliştirilmesi ve iktisadi, sosyal, kültürel vb. alanlarda işbirliğinin arttırılmasına kapı aralamıștır. Birçok ilim adamı, kendi sahalarında İslam'ın yirminci yüzyılın dünyasına söyleyecek sözleri olduğunu, değișen toplumların ihtiyacını karşılayabileceğini, iktisadi kalkınmaya destek olabileceğini ve devlet yönetimini gerçekleștirebileceğini düşünmekteydi (El- Ashker ve Wilson, 2019, s. 289). İşte bu ve benzeri arayışlar, Hindu-Pakistan menşeili ‘İslam iktisadı' kavramının gündeme gelmesine ve literatüre kazandırılmasına yol açmıştır (Zaim, 1992, s. 11). Tüm bu arayışların merkezinde, kalkınmaya destek olacak finansmanın nasıl sağlanacağı meselesi bulunmaktaydı. Bu amaca binaen İslam Kalkınma Bankası (İKB) ve diğer İslami bankalar² kurulmaya başlamış ve oldukça hızlı büyümüşlerdir. Bununla birlikte daha ziyade ulusal, bölgesel veya yerel finansman ihtiyacını karşılayan kuruluşların da sayısı artmış ancak bankacılık sisteminin gelişmesine ve sahip olduğu ekonomik büyüklüğe erișemediklerinden bu süreçte adlarından fazla söz ettirememişlerdir.

İslami bankacılığın, finansal olarak kayda değer başarılar göstermesine rağmen Müslüman ülkelerin kalkınmasına hizmet etme ve sosyal gelişmelerini sağlama hususunda başarısız olduğu birçok çalışmada ifade edilmektedir. Asutay (2012), çalışmasında, İslami bankaların kuruluş hedeflerinden uzaklaşarak sosyal başarısızlık gösterdiklerini vurgulamaktadır. Bu başarısızlıkları şu şekilde ifade etmektedir:

- $\quad$ Islami bankacılığın faaliyetlerinde konvansiyonel sistemi takip etmesi ve onunla benzeșmesi,

- IIslami bankacılığın finansallaşması,

1 Şimdiki adıyla İslam İşbirliği Teşkilatı.

2 Türkiye'deki ismi ‘Katılım Bankası'. 
- $\quad$ Kâr-zarar paylaşımına dayalı öz sermaye temelli finansman yerine borç temelli finansmana ă̆ırlık vermesi,

- Kuruluş amacı olan Müslüman ülkelerin kalkınmasına destek olma misyonundan uzaklaşması,

- $\quad$ Sosyal sorumluluk alanındaki faaliyetlerinin yetersizliği,

- İslami bir kurumsal yönetişim geliştirememesi.

Bununla birlikte, İslami bankacılığın 'Íslami'liğinin, kuruluş amaçlarından uzaklaştığını, ürün ve hizmetlerinde geleneksel finansı takip ettiğini ve diğer birçok gerekçeyle beklentileri karşılayamadığını dile getiren pek çok çalışma bulunmaktadır (Aksak ve Asutay, 2011; Beck, Demirgüç-Kunt ve Merrouche, 2013; Chong ve Liu, 2009; Gan, 2010; Hassan ve Harahap, 2010; Khan, 2010; Pollard ve Samers, 2007). Bu doğrultuda İslam iktisadının ilkelerini Asutay'ın deyimiyle 'şekilde ve özde' taşıyan alternatif kurumlara ihtiyaç bulunmaktadır. Bu kurumların kimi formel yapılar iken kimi de toplumsal ilişkilerin bir parçası olarak ortaya çıkan enformel yapılardır. Bu çalışmada, banka harici yapılardan günler ele alınmakta ve toplumsal ilişkilerin bir parçası olan bu uygulamanın, İslam iktisadının hedefleriyle örtüşmesi bakımından alternatif bir çözüm yolu olduğu vurgulanmaktadır. Müslüman dünyasının finansman ihtiyacını genel olarak banka ve banka haricindeki yapıların ${ }^{3}$ (BHY) karşıladığını ifade edebiliriz. BHY'ler de formel ve enformel olarak örgütlenmektedir. Formel olanlar faaliyet gösterdikleri alanda resmi hukuka tabii iken enformel olanlar tabii değillerdir. Enformel kurumların hukukunu çoğu zaman kurumu ortaya çıkaran kişilerin kendisi oluşturmaktadır. Bununla birlikte bu kurumların bazılarının amacı doğrudan finansman sağlamak iken bazıları finansman sağlamayı ikincil amaç edinerek yardımlaşma ve dayanışmayı öncelemektedir. Birbirinden farklı özelliklere sahip bu yapıların ortak özelliği, banka dışı finansman araçları olmalarıdır. Tablo 1, BHY'lerin genel bir görünümünü bizlere vermektedir. Her birinin kendilerine özgü özellikleri olmakla birlikte faaliyetlerinin sonucunda finansman ihtiyacını az veya çok karşıladıkları bilinmektedir. Enformel BHY'lerin en bilinenleri günler ve sandıklardır. Günler ve sandıklar genellikle kişilerin kendiliğinden bir araya gelip finansman ve sosyalleşme sağladıkları yapılardır.

BHY'ler, bankacılık sektörünün ulaşabildiği ekonomik büyüklüğe ulaşamamış olsa da son zamanlarda adından çokça söz ettirmektedir (Asutay, 2012). Tablo 1'de Türkiye'de finansman sağlayan BHY'lerin özellikleri ele alınmıştır. BHY kavramsallaştırması şu yapıları kapsamaktadır: Tasarrufa dayalı faizsiz finans sistemi (TDFFS) kurumları, tüketici finansman şirketler, finansal kiralama şirketleri, kitle fonlaması kurumları, mikrofinans kuruluşları, sandıklar ve günler.

Çalışma, BHY içerisindeki enformel bir kurum olan günlere odaklanmaktadır. Bu sebeple Tablo 1'de yer alan diğer kurumlar hakkındaki tartışmalar

3 Bu kavramsallaştırmaya kısaca banka haricindeki yapılar (BHY) demeyi tercih etmekteyiz. 
bağlamın dışında bırakılmıştır. Günlerin sağlamış olduğu finansman büyüklüğü tam olarak tespit edilemese de toplum içerisinde yaygın bir ağ oluşturdukları bilinmektedir (Eroğlu, 2010; Kahyaoglu, Alpay ve Yavuz, 2016). Her ne kadar enformel bir kurum olarak görülseler de genellikle yazılı olmayan ama katılımcılar tarafından bilinen kurallara sahiplerdir. Katılımcıların yazılı olmayan -bazen de yazılı- kurallara göre oluşturdukları denetleme mekanizmaları da bulunmaktadır. Otonom denetleme mekanizmalarına sahip olan bu kurumlar genellikle katılımcıların beklentilerine göre kuruluş amaçlarını belirlemektedir. Ayrıca dışa kapalı/grup içi finansman sağlamakta ve genelde katılım ücreti almamaktadırlar.

Tablo 1. Banka harici yapıların genel görünümü

\begin{tabular}{|c|c|c|c|c|}
\hline BHY'ler & $\begin{array}{c}\text { Yasal } \\
\text { Durum }\end{array}$ & $\begin{array}{c}\text { Düzenleyici-Denetleyici } \\
\text { Kurumlar }\end{array}$ & Birincil Amaçları & $\begin{array}{c}\text { Finansmana } \\
\text { Erişim }\end{array}$ \\
\hline TDFFS 4 & Formel & Yok & Finansman sağlamak & Grup içi \\
\hline $\begin{array}{l}\text { Tüketici } \\
\text { Finansman } \\
\text { Şirketleri }\end{array}$ & Formel & $\begin{array}{l}\text { Bankacılık Düzenleme ve } \\
\text { Denetleme Kurumu }\end{array}$ & $\begin{array}{l}\text { Finansman Sağla- } \\
\text { mak }\end{array}$ & Açık erişim \\
\hline $\begin{array}{l}\text { Finansal Kira- } \\
\text { lama Şirketleri }\end{array}$ & Formel 5 & $\begin{array}{c}\text { Bankacılık Düzenleme ve } \\
\text { Denetleme Kurumu }\end{array}$ & Finansman sağlamak & Açık erişim \\
\hline $\begin{array}{l}\text { Kitle Fonlama- } \\
\text { sı Kurumları }\end{array}$ & Formel 6 & Sermaye Piyasası Kurulu & Finansman sağlamak & Açık erişim \\
\hline $\begin{array}{l}\text { Mikrofinans } \\
\text { Kurulușları }\end{array}$ & Formel & İçişleri Bakanlığı & Finansman sağlamak & Açık erişim \\
\hline Sandıklar7 & $\begin{array}{l}\text { Formel / } \\
\text { Enformel }\end{array}$ & $\begin{array}{l}\text { Formel olanlar ilgili ku- } \\
\text { rumlar tarafından denet- } \\
\text { lenmektedir. }\end{array}$ & Finansman sağlamak & Grup içi \\
\hline Günler & Enformel & Yok & $\begin{array}{c}\text { Sosyalleşme / } \\
\text { Finansman sağlamak }\end{array}$ & Grup içi \\
\hline
\end{tabular}

Kaynak: Yazarlar tarafından geliştirilmiștir.

\section{Gün Pratiklerinin İktisadi, Sosyal ve Fıkhi Yönleri}

Rotating Savings and credit associations (rosca), farklı coğrafyalarda farklı şekillerde adlandırılsa da uygulamada çeşitli işlevleri olan bir sosyal ilişki biçimidir (Ardener, 1964, s. 201; Geertz, 1962, s. 242). Rosca kavramının tam olarak Türkçe ifadesi bulunmasa da "Dönüşümlü Tasarruf ve Kredi Birlikleri” olarak ifade edilebilir. Gana'da "Susu”, Etiyopya'da “Iqqub” (Aredo, 2004), Kamerun'da "Tchwa” (Tchuindjo, 1999, s. 6) şeklinde adlandırılan roscalar, Türkiye'de "gün" olarak adlandırılmakta ve kişilerin belirledikleri miktarda

4 Tasarrufa Dayalı Faizsiz Finans Sistemi

56361 sayılı Finansal Kiralama, Faktoring Ve Finansman Şirketleri Kanunu'na tabiidir.

6 Paya Dayalı Kitle Fonlaması Tebliği (III - 35/A.1)

7 Sandıklarla ilgili detaylı bilgi için: Genç, A. T. (2019). Türkiye’de Karz-ı Hasen Sandık Uygulamaları: Nitel Bir Araştırma. Yayımlanmamış Yüksek Lisans Tezi. Sakarya Üniversitesi. 
ve sırayla katkıda bulunarak sosyal çevreleriyle buluşarak veya buluşmayarak oluşturdukları bir grupla sürdürülen sosyal ilişki biçimini almaktadır (Eroğlu, 2010). Kișiler oluşturdukları bu grupla genellikle her ay belirlenen miktarda para, altın veya dövizi belirli bir sırada birbirlerine vermektedirler. Kurayla veya ihtiyaca göre belirlenen, sırayla birbirini görmek için vasita olarak görülen veya para biriktirmekte zorlanan kişiler için tasarruf motivasyonu sağlayan günler, Türkiye'de erkeklerden çok kadınlar arasında yaygın bir uygulama olarak görülmektedir (Büyükokutan, 2012).

Roscaların dünya genelinde görülen bir uygulama olması, kültürlere göre farklılıkları da beraberinde getirmektedir (Ardener, 1964; Geertz, 1962). Örneğin bazı Asya ülkelerindeki uygulamalarda katılımcılar birbirlerine faiz ödemektedirler (Ardener, 1964). Faiz ödenmesinin yanı sıra, roscalara katılan kișiler arasında sıranın belirlenme hususunda da farklılıklar görülmektedir. Genellikle kurayla belirlenen sıra, bazı bölgelerde teklif esasına göre de belirlenir (Aredo, 2004; Besley, Coate ve Loury, 1993; Dekle ve Hamada, 2000; Kirton, 1996). Özellikle gelişmekte olan ülkelerde üç farklı rosca tipi tanımlanmıştır; birbirleriyle sosyal bağları bulunan insanların yardımlaşma ve dayanışma amacıyla kurdukları dayanışma roscaları, bir organizatör tarafından belirli bir komisyon karşılığında fonların toplandığı ve dağıtımının yapıldığı ticari roscalar ve son olarak resmi finansal yapılara en fazla benzeyen finansal roscalardır (Kirton, 1996). Türkiye'deki yaygın olan gün uygulamaları ise, bu farklı tiplerdeki rosca uygulamaları içerisinden dayanışma roscaları gibi dayanışma ve yardımlaşma temelinde sürdürülmektedir. Bu noktada günler, sahip oldukları özellikleri dolayısıyla sosyal, iktisadi ve fıkhi açılardan incelemeye açıktırlar.

\section{Günlerin Sosyal Yönü}

Günlere sosyal açıdan bakıldığında kişilerin bir araya gelerek dertleri ve mutluluklarını paylaştığı, ailesiyle, akrabasıyla, komşusuyla görüşme fırsatı bulduğu, hem psikolojik olarak kendisini rahatlattığı hem de sosyalleşmesine imkân sağladığı bir ilişki ortamı sunmaktadır (Büyükokutan, 2012). Günler, sosyal anlamda özellikle kadınlar arasında bir boş zaman etkinliği olarak da görülmektedir (Karayiğit, 2015). Günlerde bir araya gelen kadınlar hoşça vakit geçirmekte, bilgi ve becerilerini paylaşmakta, yeri geldiğinde ise güncel konular üzerinde fikir alışverişinde bulunmaktadırlar (Büyükokutan, 2012). Meslektaşların bir araya gelerek oluşturdukları gruplar hem sosyal boyutta hem de iş hayatına önemli katkılar sağlamaktadır (Aredo, 2004). Bu tür enformel oluşumlar, dayanışmacı ve gönüllü tasarruf etme ve finansman sağlama açısından en etkili organizasyonel formları oluşturmaktadır (Sadr, 2017). 
Günlerin İktisadi Yönü

İktisadi yönden bakıldığında günlerin, katılan kişiler açısından avantajlı ve dezavantajlı yönleri vardır. Günlerin avantajlarından ilki, üyelerini tasarruf etmeye zorlamasıdır (Ardener, 1964). Günlere katılan kişiler belirli bir dönem aralığında ve sırayla birbirlerine ödeme yapma sözü vermektedir. Bu sayede güne katılan kişiler kendilerini kontrol altına alarak harcamalarını kısitlayabilmektedirler (S. Ambec ve Treich, 2003; Gugerty, 2007). Böylece gün katılımcıları bugünkü tüketimlerini erteleyerek ortalama tasarruf oranlarını arttırmaktadır (Gugerty, 2007).

Tasarrufa zorlaması avantajının yanında günler, ele geçen paranın veya altının kullanılması yönünden tüketim, sigorta ve yatırım noktasında katılımcılara fon sağlamaktadır (Aliero, 2014). Günler, tüketim açısından kişisel veya ailenin ihtiyaçlarını (dayanıklı tüketim malları, çocukların okul harcamaları, düğün/çeyiz harcamaları vb.) gideren (Aredo, 2004), sigorta yönünden kişilerin acil nakit ihtiyaçları doğduğunda yastık altında parası olmasını sağlayan (Ardener, 1964) ve yatırım yönünden olası firsatların değerlendirilmesini, araba veya ev alınmasını sağlayan, küçük girişimciler için yatırım finansmanı oluşturan müesseselerdir (Ullah, Naimi ve Yusoff, 2016).

Diğer bir avantajına bakıldığında, günlerin kolay ulaşılabilir olması ve yerellik yönünden birbirini tanıyan kişiler arasında gerçekleșmesi, formel finans piyasasında bulunan sözleşme maliyetleri gibi maliyetleri oldukça düşürmektedir (Kirton, 1996). Meslektaşlar, akrabalar gibi birbirini tanıyan ve benzer ekonomik şartlara sahip kişilerin bir araya gelerek kurdukları gün grupları, esnek ve hızlı adapte olma özelliklerine sahiptir. Katılımcı sayısı, ödenen miktar ve toplanma sıklı̆̆ı, güne katılan kişilerin yaşadığı sosyal ve ekonomik çevreye bağlı olarak değişmektedir (Sadr, 2017). Ayrıca formel finansal piyasalardan düşük gelir düzeyi sebebiyle veya düşük bireysel kredi notu gibi sebepler dolayısıyla faydalanamayan bireyler, günler sayesinde enformel bir finansman imkânı bulmaktadır (Eroğlu, 2010, s. 467).

Günlerin iktisadi yönden dezavantajlarına bakıldığında, katılımcıların ödeme sorumluluklarını yerine getirmemeleri veya yerine getirme şüphesi birinci sırada yer almaktadır (Eroğlu, 2010). Belirli bir sosyal çevreye yeni katılmış veya var olan gün grubunun tanımadığı bir kişi, günün işleyişi için risk unsuru taşımaktadır. Şüpheli durumda olan kişiler için alınan temel önlem, bu kişinin son sıraya konularak riskin en aza indirilmesidir (Ardener, 1964). Ayrıca herhangi bir gün üyesinin ödemede sorun yaşaması, grubun tümünü etkilemektir. Bu durum, günlerin dışa kapalı, kısıtlı sayıda kişi arasında gerçekleştirilmesine yol açmaktadır. Neticede bir borç ilişkisi olan gün, borcun yapısındaki kırılganlıklara sahiptir (Graeber, 2015, s. 20). Bu kırılganlıklar, ödeme konusunda şüpheli olan kişileri veya daha önceden bu sorunu yaşamış kişilerin gruptan atılmasına, bir sonraki gün grubuna dâhil edilmemesine ve sosyal açıdan itibarsız bir duruma düşmesine sebep olmaktadır. Karşılıklı güven, utanç hissi veya endișesi, sosyal baskı gibi unsurlar, katılımcıların gün 
müessesini kötüye kullanmasını önlemenin temel yollarıdır (Eroğlu, 2010). Bu dezavantaj, günlerin katılımcı yapısını oldukça etkilemektedir (Eroğlu, 2010). Güne katılan kişilerin özellikle meslekleri ve buna bağlı olarak düzenli gelir elde edip etmemesi veya daha düzenli bir iş ortamının olup olmamasına bağlı olarak günlere katılım oranları değişkenlik göstermektedir. Örneğin, gelirin sezonluk veya düzensiz olduğu mesleklerde (tarım, balıkçılık, ormancılık gibi) günlere katılım oranının daha düşük olduğu tespit edilmiştir (Levenson ve Besley, 1996, s. 53). Ödeme sorumluluğunun yerine getirilmemesinin oluşturabileceği utanç veya itibarsızlık, kişileri güne katılmaktan alıkoymaktadır. $\mathrm{Bu}$ açıdan daha düzenli gelire sahip olan kişilerin günlere katılımı kolaylaşmaktadır. Günlerdeki ödeme sorunlarının çözümü üzerine Harper (1994), günlerin müşareke (sermaye ortaklığı) yöntemi çerçevesinde geliştirilerek formelleşmesinin sağlanmasını ve bu sayede ödeme sorunlarının giderilmesini tavsiye etmektedir.

Günlerin bir diğer dezavantajı, günden alınan maddi birikimin zamanı ile harcama yapılması planlanan zamanın uyuşmamasıdır (Kirton, 1996). Daha önce de belirtildiği gibi dünyadaki uygulamalara bakıldığında sıranın belirlenmesinde temelde iki yöntem kullanılmaktadır: Rastgele (kurayla) ve teklif usulü (Besley ve diğerleri, 1993). Sıranın özellikle kurayla yani rastgele belirlendiği günlerde karşımıza çıkan bu dezavantaj, günlerin karşılaşılan maddi problemleri çözmedeki etkinliğini düşürmektedir (Besley ve diğerleri, 1993). Gün grupları bu sorunun üstesinden, sıranın ihtiyaca göre belirlenmesi veya ihtiyaç doğduğunda sıra değişimi gibi yollarla gelmeye çalışmaktadır.

\section{Günlerin Flkhi Yönü}

Öncelikle literatürde günlerin (roscaların) fıkhi yönüyle ilgili çalışmaların oldukça sınırlı olduğu belirtilmelidir. Bu konuda Aliero'nun (Aliero, 2014) müstakil çalışması, Duman'ın (Duman, 2018, ss. 240-244) Günümüz Fıkıh Problemleri kitabında "Altın-para günü yapmak" başlığılla günleri fikhi yönden değerlendirdiği kısım, Kaya'nın (Kaya, 2019, ss. 240-242) Fıkıh Konusunda 88 Soru kitabında günleri "bir fayda celbeden her türlü karz faizdir" hadisi çerçevesinde değerlendirdiği kısım ve Din İşleri Yüksek Kurulu’nun günler hakkında sorulan bir soruya verdiği cevap 8 temel alınacaktır.

Daha önce Türkiye'deki gün uygulamalarının dünyadaki rosca çeşitleri arasından yardımlaşma ve dayanışma roscaları içerisinde olduğu belirtilmişti. $\mathrm{Bu}$ çerçeveden bakıldığında gün uygulamalarının temelinde karz akdi

8 Kadınların kendi aralarında yaptıkları "gün" adı verilen toplantılarda topladıkları paraları dönüşümlü olarak almaları caiz midir? Sorusuna Din İşleri Yüksek Kurulu şu şekilde cevap vermiștir:

"Borç verme İslam'da teșvik edilen bir husustur. İnsanların muhtaç olan kișilere borç vermeleri sadaka sevabı olan bir davranıștır (İbn Âbidin, Reddu'l-muhtâr, VII, 388, 396). Borç vermede önemli olan, borç karşılığında herhangi bir fazlalığın şart koşulmaması, borç verenin ya da alanın zarara uğratılmamasıdır (Kâsânî, Bedâî', VII, 394-396). Kadınlar arasında tertip edilen toplantılarda her bir katılımcının toplanan meblağı dönüşümlü olarak her ay içlerinden birine vermeleri şeklindeki uygulamada bir sakınca yoktur. Çünkü bu, sonuçta bir borç verme işlemidir." (Din İşleri Yüksek Kurulu, y.y.) 
bulunmaktadır (Aliero, 2014; Duman, 2018; Kaya, 2019). Katılımcıların birbirine borç verdiği bir uygulama olarak günlerde dikkat edilmesi gereken en temel mesele faize bulaşılmamasıdır (Kaya, 2019). Aynı türden paraların faize bulaşmamak amacıyla eşit ve peşin değiştirilmesi gerekirken günlerde katılımclların birbirlerine verdikleri miktarlarda eşitlik sağlanırken peşin olma şartı sağlanamamaktadır. Karz-ı hasenin aynı türde paraların değişimi noktasında istisna olması, karzın ticarete dayalı bir mübadele işlemi değil, yardımlaşmaya dayalı bir işlem olması hasebiyledir (Apaydın, 2001, s. 522).

Karz akdiyle ilgili temel meselelere bakıldığında vadenin bağlayıcılığının bulunmaması ve fazladan menfaat elde etmenin yasak olması gündeme gelmektedir (Apaydın, 2001; Durmuş, 2010). Vadenin bağlayıcılığı hususunda, günler, kişilerin herhangi bir zorlama olmadan kendi rizalarıyla katılabildikleri ve ayrılabildikleri bir işleyișe sahip olmalıdır (Aliero, 2014). Bu yüzden günden ayrılmak isteyen kişiye öncelik tanınmalı ve o zamana kadar kimlere karz verdiyse bunların kendisine geri ödemesi yapılarak günden ayrılması sağlanmalıdır (Duman, 2018).

"Menfaat getiren her karz faizdir" (Apaydın, 2001) hadisi çerçevesinde düşünüldüğünde ise özellikle günü koordine eden kişinin gün sırası belirlenirken kuraya katılmayıp ilk sıraya yazılmaması, herkes gibi kuraya katılması veya günü koordine ettiği için diğer katılımcılardan fazlalık almaması gereklidir (Duman, 2018; Kaya, 2019). Bu hadis çerçevesinde gün uygulamalarında birbirine karz veren kişilerin denk fayda elde ettikleri görülmekte ve karz verenin karz alandan tek taraflı bir yararlanmasının söz konusu olmadığı belirtilmelidir (Duman, 2018; Kaya, 2019). Ayrıca Türkiye'de olmasa da özellikle Uzak Doğu ülkelerinde görülen teklif usulüne göre sıranın belirlendiği ve kişilerin birbirine verdiği para miktarının farklı olduğu "bidding rosca" türlerinin fikhen uygun olmadığı da belirtilmelidir (Aliero, 2014).

\section{Yöntem}

Bu bölümde araștırmanın yöntemi, çalışma grubu ve örneklemi, verilerin toplama süreci ve analizi hakkında bilgiler sunulacaktır.

\section{Araştırmanın Yöntemi}

Bu çalışmada, para-altın ve döviz günlerinin işleyişlerini ve katılımcıların özelliklerini keşfetmek ve günlere katılımı etkileyen faktörleri tespit etmek amacıyla karma yöntem tercih edilmiştir. Karma yöntem hem nitel hem de nicel yöntemlerin birlikte kullanılarak araştırma probleminin daha iyi anlaşılmasını sağlar (Creswell, 2019, s. 697). Karma yöntemde farklı yöntemlerle elde edilen veriler harmanlanarak, ilișkilendirilerek konunun bütüncül bir şekilde ele alınması kolaylaştırılır. Karma yöntemin, hem istatistiki (nicel veriler) hem de öykü ve kişisel deneyimleri temsil eden (nitel veriler) bilgiler içermesi, araştırma problemini daha iyi anlamaya ve bu verilerin 
birleștirilmesi ile araştırılan olguyu, yöntemlerin tek başlarına olduklarından daha fazla açıklamaya hizmet ettiği bilinmektedir (Creswell, 2017:2).

Çalışmada karma yöntem desenlerinden keşfedici ardışık desen tercih edilmiştir. Keşfedici ardışık desen, üzerinde çalışılan olgunun öncelikle nitel yöntemle derinlemesine farklı boyutlarının keşfedilmesini, daha sonrasında ise nitel verilerden edinilen ilişkileri açıklamak amacıyla nicel verilerin toplanması ile sürdürülür (Creswell, 2019, s. 708). Bu sayede araştırılan olgu bütüncül bir bakış açısı ile ele alınır.

Çalışmanın nitel kısmında gün olgusunun işleyişini, güne katılan kişilerin özelliklerini, güne katılmanın nedenlerini, katılımcılar nezdinde günün fıkhi, iktisadi ve sosyal yönlerini keşfetmek amacıyla nitel bir analiz yöntemi olan mülakata başvurulmuştur. Hâlihazırda güne katılan veya gün deneyimi olan kişilere, katılmış oldukları günlerin işleyişi, gün katılımcılarının özellikleri, günün iktisadi, sosyal çıktılarını, günlere dair fıkhi farkındalıklarını ortaya koymak amacıyla sorular sorulmuştur. Nitel verilerden elde edilen bilgiler değerlendirilerek ve literatürden faydalanılarak günlere katılımı etkileyen temalar belirlenip, nicel bir analiz yöntemi olan anket aracılığıly bu temalar daha geniş bir kitleye sunulmuştur. Çalışmanın süreçleri aşağıdaki şekilde gösterilmektedir:

Şekil 1. Araştırma süreci

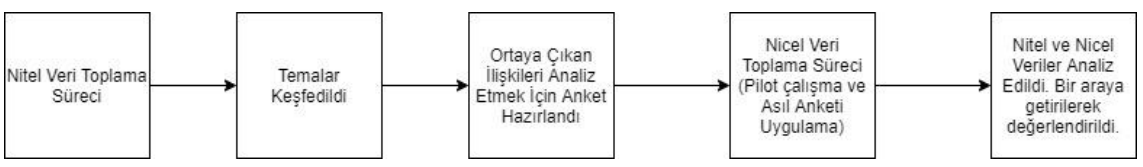

Kaynak: Yazarlar tarafından hazırlanmıştır.

\section{Araştırmanın Çalışma Grubu ve Örneklemi}

Araştırma örneklemini oluştururken temel hedef, araştırma problemini ve sorularını en iyi şekilde anlayan katılımcıları seçmektir (Creswell, 2017a: 189) Bu hedefe ulaşmak için ilk aşamada "amaçlı örnekleme" yöntemi tercih edilmiştir. Çünkü amaçlı örnekleme, örnekleme dair bilgi edinmenin zor olduğu olgu, konu veya olaylarda detaylı bilgi edinme olanağı sağlamaktadır (Neuman, 2014: 323). Nitel aşamadaki çalışma grubu hâlihazırda güne katılan veya daha önce gün deneyimi olmuş 9 katılımcıdan oluşmaktadır. Katılımcıların ikisi ev hanımı, üçü esnaf, ikisi memur ve ikisi işçidir. Farklı meslek gruplarının tercih edilmesinin nedeni, farklı meslek gruplarına mensup kişilerin gerçekleştirdiği günlerde ortaya çıkan farklılıkların keşfedilmesinin amaçlanmasıdır (Levenson ve Besley, 1996, s. 53). Kocaeli'den iki esnaf, İstanbul'dan iki işçi ve diğer yedi katılımcı Sakarya'dan olmak üzere dokuz kişiyle yapılan mülakat incelemesi aşağıda yer almaktadır. 
Tablo 2. Mülakat yapılan kişilerin demografik bilgileri ve katıldıkları günlere dair bilgiler

\begin{tabular}{|c|c|c|c|c|c|c|c|c|c|}
\hline Kod & Cinsiyet & Meslek & $\begin{array}{c}\text { Çalışma } \\
\text { Yılı }\end{array}$ & $\begin{array}{l}\text { Gündeki } \\
\text { Pozisyonu }\end{array}$ & $\begin{array}{c}\text { Gündeki } \\
\text { Kişi Sayısı }\end{array}$ & $\begin{array}{c}\text { Gün } \\
\text { Buluşması }\end{array}$ & $\begin{array}{c}\text { Gün } \\
\text { Döngüsü }\end{array}$ & \multicolumn{2}{|c|}{$\begin{array}{l}\text { Bir Döngüdeki } \\
\text { Toplam Tutarı }\end{array}$} \\
\hline K1 & Kadın & $\begin{array}{c}\text { Ev } \\
\text { Hanımı }\end{array}$ & - & Üye & 12 & Var & Aylık & $\begin{array}{l}1.200 \\
\mathrm{TL}\end{array}$ & - \\
\hline K2 & Kadın & $\begin{array}{c}\text { Ev } \\
\text { Hanımı }\end{array}$ & - & Koordinatör & 7 & Var & Aylık & $700 \mathrm{TL}$ & - \\
\hline K3 & Erkek & Esnaf & 11 & Koordinatör & 15 & Yok & Aylık & $\begin{array}{c}15.000 \\
\text { TL }\end{array}$ & - \\
\hline K4 & Erkek & Esnaf & 25 & Üye & 10 & Yok & $\begin{array}{l}\text { İki Haf- } \\
\text { talık }\end{array}$ & $\begin{array}{c}10.000 \\
\text { TL }\end{array}$ & - \\
\hline K5 & Erkek & Esnaf & 10 & Koordinatör & 21 & Yok & Haftalık & $\begin{array}{c}3.150 \\
\text { TL }\end{array}$ & - \\
\hline K6 & Erkek & Memur & 6 & Üye & 12 & Var & Aylık & - & $\begin{array}{l}12 \mathrm{gr} \\
\text { altın }\end{array}$ \\
\hline K7 & Erkek & Memur & 3 & Koordinatör & 12 & Var & Aylık & - & $\begin{array}{l}12 \mathrm{gr} \\
\text { altın }\end{array}$ \\
\hline K8 & Erkek & İşçi & 11 & Üye & 11 & Var & Aylık & $\begin{array}{c}1.650 \\
\mathrm{TL}\end{array}$ & - \\
\hline K9 & Erkek & İşçi & 21 & Üye & 10 & Var & Aylık & - & $\begin{array}{c}10 \\
\text { çeyrek } \\
\text { altın }\end{array}$ \\
\hline
\end{tabular}

Nitel bulgulardan elde edilen bilgilerin ilişkilendirilmesi ve daha geniş bir kitleye açıklanması amacıyla araştırmanın nicel aşamasında anket yöntemiyle 420 katılımcıya ulaşılmıştır. Fakat ankette katılımcıların anketi okuyup okumadığını tespit etmek amacıyla yer alan kontrol sorusuna 349 katılımcının doğru cevap verdiği görülmüş ve analiz 349 katılımcıdan elde edilen veriler ile gerçekleştirilmiştir. Katılımcıların \%53'ü Sakarya, \%19’u İstanbul, \%7’si Kocaeli ve \%7'si Ankara başta olmak üzere 29 farklı şehirden ankete katılım sağlamıştır.

Veri Toplama Yöntemi ve Araçları

Araştırmada nitel verileri elde etmek için yarı yapılandırılmış mülakat tekniğinden faydalanılmıştır. Bu teknik, çalışma grubunun olgu hakkındaki düşüncelerine yönelik standart sorular sorulmasına yardımcı olduğu kadar görüşme esnasında farklı boyutlara dair sorular sorma açısından da esneklik sağladığından tercih edilmiştir. Mülakat gerçekleşmeden önce literatürden yola çıkarak araștırılan ana olguya yönelik sorular hazırlanmıştır. Bu noktada yarı yapılandırılmış mülakat tekniğinden faydalanılmıștır.

Nitel aşamada görüşmelerin hepsi katılımcıların belirledikleri bir zamanda, iş yerlerinde gerçekleştirilmiştir. Ev hanımlarıyla görüşmeler evlerinde gerçekleştirilmiştir. Mülakatlar katılımcılardan izin alınarak ses kayıt cihazı ile kaydedilmiştir. Mülakat esnasında gerektiğinde ilave sorular sorulmuş ve bunlar not edilmiştir. Kaydedilen mülakatların daha sonra dökümü yapılmış, Nvivo 10 programına yüklenerek analiz edilmiştir. Bulgular çerçevesinde belirli 
temalar ortaya çıkarılmıştır. Çalışmanın nitel aşamasının güvenirliğini sağlamak amacıyla katılımcılara elde edilen sonuçlar özetlenmiş ve onay alınmıştır. Ayrıca belirttikleri ifadelerin alıntı yapılmasına yönelik izinler alınmıştır.

Araştırmanın nicel kısmında Kahyaoğlu vd.'nin (2016) çalışmalarında kullandığı anket, yazarlardan talep edilmiş ve izinleri çerçevesinde nitel verilerden de yola çıkarak geliştirilmiştir. İlk olarak anketin katılımcılar tarafından anlaşılmayan sorularını tespit etmek amacıyla 105 katılımcı ile pilot çalışma gerçekleștirilmiştir. Gerekli düzenlemeler yapılıp ankete son hali verilmiştir. Buna göre anketin ilk kısmı katılımcılar hakkındaki 8 demografik sorudan, ikinci kısmı katıldıkları günlerin özelliklerini belirten 7 sorudan ve son olarak günlere katılımı etkileyen faktörleri tespit etmek amacıyla 35 soruluk 5'li likertten oluşmaktadır. Kolayda örnekleme yöntemi ile 349 katılımcı ile gerçekleştirilen anketlerden elde edilen veriler SPSS 25.0 programına yüklenmiştir. Elde edilen verilerin analizinden önce geliştirilen ölçeğin anlamlılığı test edilmiş ve daha sonra veriler analiz edilmiştir.

\section{Nitel Çalışma Bulguları}

Araştırmada katılımcılara günlerin işleyişi, güne katılanların özellikleri, günlerin iktisadi çıktıları ve günlerin fıkhi yönlerine dair yarı yapılandırılmış bir mülakat yapılmıştır. Mülakatlar deşifre edilip nitel incelemeye tabi tutulduğunda, katılımcıların düşünce dünyasındaki gün olgusuna yönelik sekiz tema olduğu keşfedilmiştir. Bu temalar şunlardır: Güven, sosyalleşme, dayanışma, dini hassasiyet, tasarruf, yatırım, tüketim ve finansal piyasalara erişememe.

\section{Güven}

Güven, her türlü ilişkinin en temel bileşenlerinden olan, varlığı durumunda ilişkilerin sürdürülme ve güçlenme olasılığını yükselten, yokluğunda ise ilişkileri kırılgan bir noktaya taşıyan kavramdır. Araştırmada güven temasının her katılımcı tarafından önemle vurgulandığı, günlerin ve gündeki kişilerin güven ağlarıyla birbirlerine bağlı oldukları tespit edilmiştir. Güven, iki alt temayla çalışmada yer bulmaktadır. İlki, güvenilir ve çevresi tarafından itibar gören kişilerin günlere alınması anlamına gelen 'kişilere güven'; ikincisi ise gün sisteminin katılımcıların hayatında 'güvence' olmasıdır. 
Tablo 3. Güven teması

\begin{tabular}{llll}
\hline Tema & Alt Tema & Kod & $\begin{array}{l}\text { Frekans } \\
\text { (n) }\end{array}$ \\
\hline \multirow{3}{*}{ Güven } & \multirow{2}{*}{ Kişilere güven } & Tanımak & 34 \\
& & Ekip & 12 \\
& & Güvenilir & 10 \\
& & Sözünün eri/sözünü tutan & 4 \\
\cline { 3 - 3 } & Sira değișikliği & 15 \\
& \multirow{2}{*}{ Güvence } & Kefil & 12 \\
& & Güven esaslı yapı & 6 \\
& & Ödeme planlaması & 5 \\
& & \\
\hline
\end{tabular}

K3: "Zaten bu iş güvene dayalı olduğundan, günün içindeki herkes birbirini tanımasa da bu işi organize ettiğimiz için biz herkesi tanıyoruz. Diğer arkadaşların çoğu birbirlerini tanımıyor ve muhabbetleri de fazla yok. Ama güven esaslı bir organizasyon olduğu için bu arkadaşlar biz seni tanırız, diğerlerini tanımayız, bir problem olursa sana geliriz diye söylüyorlar."

K4: “Herkesi tanımıyorum. Tanımadıklarım, günü yapan kişinin tanıdığı, güvendiği kişilerdir. Günü organize eden kişiye güveniyorsam diğerlerini tanımiyor olmama takılmıyorum."

K5: "Her şeyden önce çoğunluğu burada esnaf arkadaş; güvenilir olmasına bakıyoruz. Yani sözünün eri mi, bir sıkıntı yaşanır mı, bunlara bakıyoruz."

K6: "Günün çekirdeğinde 3 kişi var. Bu üç kişinin güvendiği arkadaşlarıyla oluştu bu gün."

K7: "Her iki günde de güven esasını sağlayan kişiler güne katılabiliyor. Güven konusunda ortak paydamız var."

Görüldüğü üzere güven, güne katılacak kişilerde bulunması gereken şartlardandır; bu şartı sağlamayan kişiler, gün gruplarından hızlıca uzaklaştırılmakta ve kendisiyle güvene dayalı ilișki kurulmamaktadır.

K3:"Genelde esnaf arkadaşları güne alıyoruz. Bu tecrübeyle oldu. İlk zaman, geç getiren sıkıntılı olan kişiler diğer arkadaşların da rızasıyla günden uzaklaştırıldı. Şimdiki arkadaşlar problemsiz. Örneğin güne yeni biri katacağımız zaman grup içerisinden birinin kefil olmasıyla bunu yapıyoruz."

Bununla birlikte, esnaflar arasında yaygın bir uygulama olan günler genellikle nakit akışlarını düzenlemede güvence olmaktadır. Esnaflar, gün birikimlerini alacağı tarihe ödemelerini planlayarak nakit akışlarını güvenceye almaktadır. Görüldüğü gibi gün olgusu burada kendilerine bir güvence sağlamaktadır.

9 Frekans, mülakatlarda kodları oluşturan kavramların benzer ve eşanlamlılarını da 
K4: "Önümüzdeki hafta günden alacağım para bir güvence oluyor."

K5: "Onun haricinde ödemelere denk geliyor, ödemeleri o zamana ayarlıyoruz. Çoğunluk bu şekilde zaten..."

\section{Sosyalleşme}

Daha ziyade kadınlar arasında yaygın olan ve halk arasında 'gün oturması/ kısır günü/ altın günü' vb. şekillerde karşılık bulan örneklerde sosyalleşme teması ağırlık kazanmaktadır. Bu günlerde kadınlar evlerde veya 'dışarıda' bir araya gelerek vakit geçirmekte ve sosyalleşme sağlamaktadır. Bu tarz günlerdeki meblağlar genellikle çok yüksek olmamakta ve bunun yanında temel amaçları görüşmek olduğundan kadınlar genellikle günden aldıkları parayı kullanmamaktadırlar. Ancak bununla birlikte eski dostların tekrar bir araya gelmesi ve iş arkadaşlarının muhabbetlerini sürdürmesi gibi birçok gerekçeyle erkekler arasında da sosyalleşme motivasyonuyla güne katılım vuku bulmaktadır. Teması

Tablo 4. Sosyalleşme teması

\begin{tabular}{llll}
\hline Tema & Alt Tema & Kod & $\begin{array}{l}\text { Frekans } \\
\text { (n) }\end{array}$ \\
\hline \multirow{3}{*}{ Sosyalleşme } & - & Görüşme & 14 \\
& Bir araya gelme & 13 \\
& Buluşma & 13 \\
& Akrabalarla görüşme & 8 \\
& Komşu & 8 \\
& Toplanma & 7 \\
& Akran & 4 \\
\hline
\end{tabular}

K1: “Akraba ve komşularla görüşmek, toplanmak, çünkü gelen paranın aynı şekilde gideceğini bildiğimiz için para bize destek olmuyor.

...Ben aldığım zaman gün paramı kenara koyuyorum, sırası gelen arkadaşa giderken parayı tekrar oradan götürüyorum o parayı kullanmıyorum yani."

K2: "Kullanmıyorum, kenarda tutuyorum; aydan aya geri götürüyorum ama diğer arkadaşlarda değerlendiren oluyor."

K6: "Herkes o günün gelmesini bekliyor ve nerede buluşacaklarını konuşuyorlar. 0 gün saatlerce muhabbet oluyor."

K7: "Bütün aile olarak bir yerdesiniz ve sosyalleşiyorsunuz. Gün sayesinde komşular birbirleriyle tanışıyorlar ve daha çok dayanışma içinde hareket ediyorlar."

Burada günün maddi bir yükümlülük oluşturarak sosyalleşmeye hizmet ettiğini de ifade etmek gerekir. Kişilerin kendilerini bilinçli bir şekilde yükümlü kılarak dost ve akrabalarıyla görüştüğü anlaşılmaktadır. 
K6: "Her ay buluşalım dense büyük ihtimalle olmayacaktır. Ama araya bir çeyrek altın zorunlu katılmış... Bir yükümlü kılınmış oluyor kişiler. Buluşmayı zorunlu hale getiriyor. Bu gün uygulaması da insanların kendi arasındaki ilişkilerinin gelişmesine de çok faydalı."

\subsection{Dayanışma}

Güven ağlarıyla bir araya gelen gün üyeleri, birbirlerinin ihtiyaçlarını karşılama ve sıkıntılarını giderme konusunda duyarlılığa sahip bir șekilde dayanışma sergilemektedir. Katılımcıların her birinin gündeki diğer katılımcıya yönelik olumlu bir tutuma sahip olduğu ve ihtiyaç oluşması durumunda onlara destek olmayı istediği keşfedilmiştir. Bu doğrultuda gün organizasyonlarında grup içi dayanışmanın yaygın olduğunu söylemek mümkündür.

Tablo 5. Dayanışma teması

\begin{tabular}{llll}
\hline Tema & Alt Tema & Kod & $\begin{array}{l}\text { Frekans } \\
\text { (n) }\end{array}$ \\
& & \\
\hline \multirow{3}{*}{ Dayanışma } & - & Yardımlaşma & 11 \\
& & Sikıntı giderme & 11 \\
& Gönüllü olma & 11 \\
& Dayanışma & 10 \\
& Destek & 4 \\
& Paylaşma & 3 \\
\hline
\end{tabular}

K3: "Güne katılan birinin bir sıkıntısı olduğunda ona öncelik tanıyoruz."

K4: "Genelde esnaflar birbirleriyle dayanışma ve nakit sıkıntısını absorbe etmek için giren kişilerdir."

K7: "Gün sayesinde komşular birbirleriyle tanışıyorlar ve daha çok dayanışma içinde hareket ediyorlar."

K9: "Günler insanın sıkıntısını gidermek maksadıyla yardımlaşma ve dayanışma için kurduğu yapılardır."

Günlerde dayanışma, sıra değişikliği, mühlet tanıma ve bazı durumlarda durumu müsait olmayan kişi yerine ödeme yapma şeklinde de gerçekleşebilmektedir. Kişiler güven ağıyla oluşturdukları yapıyı, dayanıșmayla kuvvetlendirmekte, böylece kişiler arasındaki ilişkiler pekişmektedir.

K7: "Benim oturduğum apartmanda bir gün oldu. 0 güne dâhil olan karşı komşu işten çıkmıştı. Onu da hallettik. Komşuyuz yüz yüze bakıyoruz. Ben ona destek olmuștum."

\section{Dini Hassasiyet}

Katılımcılar arası ilişkiler, günün işleyiş̧i ve günün diğer konvansiyonel araçlarla mukayesesi bağlamında dini hassasiyet temasının önemli bir ağırlık kazandığını söyleyebiliriz. İlk olarak, katılımcıların gün uygulamasının faiz 
taşımadığı ve aralarında dayanışma oluşturduğu kanaatine sahip olduğunu belirtmek gerekir. Bunun yanı sıra gün aracılığıyla kendilerini yükümlü kılarak komşuluk ilişkilerini ve sıla-i rahimi kuvvetlendirdiklerini de ifade etmek gerekir.

Tablo 6. Dini hassasiyet teması

\begin{tabular}{|c|c|c|c|}
\hline Tema & Alt Tema & Kod & $\begin{array}{l}\text { Frekans } \\
\text { (n) }\end{array}$ \\
\hline \multirow{11}{*}{ Dini Hassasiyet } & \multirow{8}{*}{ Faiz Hassasiyeti } & Faiz içermeme & 20 \\
\hline & & Uygunluk & 12 \\
\hline & & Bankayı tercih etmeme & 11 \\
\hline & & Kredi kartıyla harcama yap- & 8 \\
\hline & & mak yerine gün birikimini & 6 \\
\hline & & tercih etme & \\
\hline & & Hassasiyet & \\
\hline & & Bereket & \\
\hline & \multirow[t]{2}{*}{ Akraba İliş̧kileri } & Sila-i rahim & 11 \\
\hline & & Razı olma & 7 \\
\hline & Kul hakkı & Hakkını helal etme & 7 \\
\hline
\end{tabular}

K3: "Hem fazla bankaya bulaşmadan, para kaybı yaşamadan, faize girmeden ve hem haram olduğu için böyle yaptığımızda insanları teşvik de etmiş oluyoruz.

...faize girmeden paraya ulaşmak istemesidir. Birine bu devirde 3.000 TL'den fazla borç veremiyorsun. Bu durumda bankaya gittiğinde faizi bindiriyorlar.

[Günler] günümüzde faizsiz, menfaat olmadan, birilerini sıkıp üzmeden toplu para alabileceğimiz tek yol olduğu içi tercih ediliyor."

K6: "Yani finansal amaçla girenler de var ama genel olarak faiz hassasiyeti olduğunu düşünüyorum. Faizin haram olduğunu ve faizli bankaların tamamen uzak durmamız gereken kurumlar olduğunu biliyoruz."

K5: "Her şeyden önce faiz olayı yok, sadece birbirini tanıyan insanların birbirleriyle yardımlaşma dayanışma için yaptığı bir olay."

Bununla birlikte gün üyeleri, TL ile yapılan günlerde enflasyon farkından dolayı ortaya çıan hak kayıplarına yönelik 'helalleş'tikleri ve bir sonraki günde altın veya diğer para birimlerini tercih ettiklerini söylemektedir.

K6: "Yani ilk alanla son alanlar arasında enflasyon farkı nedeniyle hak geçtiği konusunda bildirimler yaptık. İsterseniz burada telafi etmek için bir şeyler yapalım dedik. Enflasyona göre güncelleyelim dedik ama burada herkes hakkını helal ettiler. Biraz da İslam'da iyi borç vermek, yani üstüne artı almadan aynı miktarda geri almak mümkünse eğer durumu kötüyse hiç almamak düsturu 
arkadaşlarda olduğu için enflasyon farkı almadık. Ama böyle bir anormallik olma durumu Türkiye'deki günlerde çok fazla.

...Son günde de bana sonuncu sırada çıtıtı. Biz ekonomik gerekçeleri bilerek girdik; herhangi bir kayıp olursa haklarımızı helal ettik. Ki bu günde öyle bir şey yok; herkes altın bazında girdiği için 1 gr altın almış olacak."

Dini bir vecibe olarak akrabayla görüşmeyi sürdürmede ise gün vasıta olarak kullanılmakta, kişiler devamlılığını önemsedikleri bu ilişkilerde kendilerini gün vesilesiyle yükümlü kılmaktadır.

K6: "Herkes altınları getiriyor ve o ay, gün çıkan kişi de en fazla 150 TL olacak şekilde yemek hesaplarını ödüyor. Benim çok hoşuma giden bir şey, benim yakın akrabalarımın olduğu bir organizasyon. Nelerle uğraştıklarını buluşup konuşma imkânı oluşuyor. Yoksa bayramdan bayrama kalıyor veya cenazelerde görüşüyorsun. Biraz sıla-i rahim yapmak zorlaştı bu zamanlar. Bu günler onu sağlamış oluyor, güzel de oluyor."

Ayrıca günlerin dinen meşruiyetine dair sorulan soruda, daha ziyade kadın katılımclların gündemine faizden ziyade 'dedikodu' geldiği keşfedilmiştir.

K2: "Evet araştırdık, çoğu hocalar uygun olmadığını söylüyor ama tek sebebin dedikodu merkezi halini aldığı için yoksa sorun yok."

Tasarruf

Katılımcıların günler aracılığıyla harcamalarını kıstıkları, zorunlu olarak tasarruf yaptıkları ve normal şartlarda elde edemeyecekleri birikimlere ulaştıkları keşfedilmiștir. Böylece günler katılımcılar için harcamaları kısma, birikimleri arttırma işlevini yerine getirmektedir.

Tablo 7. Tasarruf teması

\begin{tabular}{lccc}
\hline Tema & Alt Tema & Kod & $\begin{array}{c}\text { Frekans } \\
(\mathrm{n})\end{array}$ \\
\hline Tasarruf & - & Birikim & 24 \\
& & Tasarruf yapma & 11 \\
& & Zorunlu tasarruf yapma & 7 \\
\hline
\end{tabular}

K3: "Bu hafta Cuma günü bir organizasyon yapacaksam gün parasında eksik varsa o programı erteliyorum."

K5: “En basit yoldan kendi paramızı değerlendirmek adına birikim yapmak adına böyle bir şey yapıyoruz.

... Ama nedir böyle bir parayı normal şartlarda kenara koyma imkânımız var mı? Var ama sıkıştığımızda kullanma imkânımız da var. 0 yüzden gün burada zaruret doğurduğu için daha güzel bir olay oluyor." 
K6: "Ekonomik etkisi, aylık harcama limitimi azaltıyor. Aylık harcamalarımı kısmama neden oluyor. Birden fazla güne katılıyorum. Ancak toplu para geldiğinde rahatlık gelecek. Zorunlu tasarruf yaptırmış oluyor, hoşuma gidiyor yani."

K8: "Hep en son alıyorum ben. 0 şartla giriyorum ben. Sonda olursam mecbur ödüyorum. Tamamen birikim amaçlı olduğu için ona yönelik."

Tasarruf yapmakta güçlük çeken kişilerin gün sırası olarak en sonda olmayı tercih ettiği ve zorunlu tasarruf yaptığı yukarıdaki katılımcıda açık bir şekilde görülmektedir.

\section{Yatırım}

Katılımcılar, girmiş oldukları günün tutarına göre gün birikimlerini değerlendirmektedir. Genellikle güne katılımın sosyalleşme motivasyonuyla gerçekleştiği örneklerde, gün birikimlerinde yatırım hedeflenmezken düzenli gelire sahip işçi, memur ve bunlarla birlikte esnaflar için günler önemli bir yatırım fırsatı sunmaktadır. Katılımcıların günler vasıtasıyla ev, araba aldıkları veya kazanç getirecek bir ticaret yaptıkları keşfedilmektedir.

Tablo 8. Yatırım teması

\begin{tabular}{lccc}
\hline Tema & Alt Tema & Kod & $\begin{array}{c}\text { Frekans } \\
(\mathrm{n})\end{array}$ \\
\hline Yatırım & - & Araba & 9 \\
& & Yatırım & 4 \\
& & Ev & 3 \\
& & Kazanç & 2 \\
\hline
\end{tabular}

K4: "Mesela, evimi alırken birisinden borç almıştım ve günden gelen parayla bu borcu ödedim. Yani o zaman iyi bir meblağdı. Bir sefer de arabamın peșinatı için kullandım."

K6: "12-13 arkadaş toplandık, düzgün meblağ belirleyelim ve yatırım yapalım dedik. Meblağlar 1.000-2.000 TL arası herkesin durumuna göre belirleniyor. Yaklaşık aylık 15.500 TL topluyoruz. Bunu birikim yapmak ve kazanç sağlamak amacıyla kurmuştuk. İlk yatırımımız kolay, bir müteahhitten daire almak. Müteahhit herhangi bir faiz almadan 24 taksitle daireyi 350.000 TL'ye satıyor. Şu an 8. aydayız, her ay adama 15.000 TL'ye yakın para ödüyoruz. 12. ayda daireyi teslim edecek. Erken teslim ediyor. Biz burada paraları toplayarak birikim oluşturmaya çalışacağız. 12. ayda elimizde bir 350.000 tl olacak ve ödeme kapasitemiz de var. Bunlarla bir arsa veya 2 daire alabiliriz. Burada eğer biz daireyi müteahhitten krediyle almaya karar verseydik, daha dezavantajlı olurdu. Bizim ödediğimiz meblağ kredi taksitlerinden çok daha az. Bankaya ödediğin paranın yarısı gibi bir miktarla bu işi 10 sene devam ettirsek gruptaki herkes ev sahibi oluyor. Bu işin çok daha kârlı olduğunu düşünüyorum." 
K9: "İhtiyacı karşılaması veya birikim yapmasına olanak sağlayan bir işleyiştir. Ya da yatırım maksadıyla kullanılmasıdır."

Tüketim Teması

Katılımclar günlere dâhil olduklarında, gün birikimleri tüketim amaçlı da kullanılmaktadır. Araştırmada gün olgusunun tasarruf ve yatırım sağlamakla birlikte ciddi anlamda tüketim talebi oluşturduğu keşfedilmiştir. Kişiler gün birikimlerini alacağı tarihe tüketimlerini ötelemektedirler.

Tablo 9. Tüketim teması

\begin{tabular}{lccc}
\hline Tema & Alt Tema & Kod & $\begin{array}{c}\text { Frekans } \\
(\mathrm{n})\end{array}$ \\
\hline Tüketim & & İhtiyaç karş1lama & 13 \\
& - & Harcama yapma & 8 \\
& & Tatil & 4 \\
\hline
\end{tabular}

K5: "Mesela bu hafta cumartesi teslim ettiğimiz arkadaş 2 hisse girmişti güne. İlkini bu hafta aldı, ikincisini de beş altı hafta sonra alacak. Ben bu iki parayı tatil parası olarak ayırdım. Bu iki parayı kullanmayacak, tatil parası olarak ayarlayacağım dedi."

K6: "Çalıştığımız arkadaşlarla yaptığımız gün tamamen finansal amaçlı bir gün. Belirli bir miktarda para gelsin. İnsanlar da o günlere göre plan yaparak harcama yapsinlar."

K7: "Büyük bir borcumu kapadım. Önceki gün sıralarında, evimin ihtiyacını karşıladım. Diğerinde bir ilkokula bağışlamıştım."

K9: "[Gün birikimlerimi] Bir ihtiyacı karşılamak için kullanıyorum."

Formel Finansal Piyasalara Erișememe

Gün katılımcılarının bazılarının formel finansal piyasalara erişimi olmadığından günlere katıldığı, bazılarının ise dini hassasiyetlerinden dolayı formel piyasa araçlarını tercih etmeyerek günlere katıldığı keşfedilmiştir. Burada katılımcıların konvansiyonel finansal araçları tercih etmediğini söylemek doğru olmamaktadır. Görüşmeler esnasında neredeyse tüm katılımcıların konvansiyonel araçlara aşina ve birçoğunun kredi kartına sahip olduğu gözlemlenmiştir. Ancak bir kısmının dini hassasiyetlerinden dolayı ihtiyaç olmadıkça bunları kullanmadığını ifade ettikleri tespit edilmiștir. 
Tablo 10. Formel finansal piyasalara erișememe teması

\begin{tabular}{lccc}
\hline Tema & Alt Tema & Kod & $\begin{array}{c}\text { Frekans } \\
(\mathrm{n})\end{array}$ \\
\hline $\begin{array}{l}\text { Formel } \\
\text { Finansal Piyasalara } \\
\text { Erişememe }\end{array}$ & - & Sicili bozuk olma & 1 \\
\hline
\end{tabular}

K3: "Hem fazla bankaya bulaşmadan, para kaybı yaşamadan, faize girmeden ve hem haram olduğu için böyle yaptığımızda insanları teşvik de etmiş oluyoruz; bazılarının da -bankalarda sicili bozuk olanlar- bankadan para çekemiyor, bunlara da fırsat sağlıyoruz."

K4: "Nakit parayı kullanmak daha çok hoşuma gidiyor. Kredi kartı kullanmayı çok tercih etmiyorum. Pek tasvip etmiyorum. Mecbur kaldığımda kredi kartını kullanıyorum."

\section{Nicel Yöntemden Elde Edilen Bulgular}

Çalışmada güne katılan 420 katılımcıya uygulanan ankette verilerin güvenirliğini arttırmak amacıyla sorulan kontrol sorusuna 349'u doğru cevap vermiş ve bu 349 katılımcının cevapları analiz edilmiştir. Ankete katılanların demografik özelliklerine bakıldığında 211'inin kadın $(\% 60,5)$ ve 138 'inin erkek (\%39,5), 18-77 yaşları arasında ve ortalama yaş düzeyinin 35,60 olduğu görülmektedir. Katılımcıların eğitim düzeyi dağılımlarına bakıldığında $\% 58,7$ 'sinin lisans ve lisansüstü eğitim aldığı görülmektedir. Hanehalkı ortalama gelir düzeyinin 6.540€ olduğu örneklemin \%32,4'ü devlet memuru, \%21,8'i ev hanımı, \%18,1'i işçi ve \%14'ü serbest meslek sahibidir.

Kişilerin katıldığı günlerin özelliklerine bakılacak olursa çoğunlukla Türk Lirası $(\% 87,1)$ üzerinden ve 7-12 kişi arasında (\%65) gerçekleştirilen günler olduğu tespit edilmiştir.

Güne katılan kişilerin gün için evde (veya kafede) bir araya gelip gelmeme tercihlerine bakıldığında katılımcıların \%63'ü evde veya kafede bir araya gelirken, \%37'si bir araya gelmemektedir. Güne katılan kişilerin gündeki ödeme yolu tercihlerine bakıldığında katılımcıların \%80,8'i günlerde elden ödemeyi tercih ederken, \%19,2'si gün ödemelerini banka aracılığıyla yapmaktadır. Günlerin daha çok birbirini tanıyan ve yakın çevresindeki kişiler arasında gerçekleşmesi hem ödemelerin elden yapılmasını hem de katılımcıların evde veya kafede bir araya gelmesini kolaylaştırmaktadır.

Güne katılan kişilerin, günün toplanma sıklığı tercihlerine bakıldığında katılımcıların \%85,4 gibi çoğunluğu ayda bir toplanmaktadır. Türkiye'de çoğu meslekte maaş ödemelerinin aylık olduğu düşünüldüğünde günlerin çoğunluğunun ayda bir toplanması olağan bir duruma işaret etmektedir. Ayrıca günlere katılımda düzenli gelirin önemi göz önüne alındığında (Eroğlu, 2010, 
s. 466), bireylerin gelirini elde ettiği sıklığa göre toplanma sıklıklarını belirlemesi gerekmektedir.

Güne katılan kişilerin gündeki sıra belirleme biçimi tercihlerine bakıldı̆̆ında katılımcıların \%65,6'sı gündeki sıralamayı kurayla belirler iken \%34,4'ünün katılımcıların ihtiyacına göre sırayı belirlediği görülmektedir.

Güne katılan kişilerin meslekleri ile evde (veya kafede) bir araya gelip gelmedikleri arasındaki ilişkiyi belirlemeye yönelik yapılan likelihood ratio ilişki testi sonucuna göre, güne katılan kişilerin meslekleri ile evde (veya kafede) toplanıp toplanmadıkları arasında anlamlı bir ilişki bulunmaktadır (LHR(5)=38,985; p=0,000). Ev hanımlarının \%84,2'si evde veya kafede bir araya gelirken, serbest meslek sahiplerinin $\% 55,1^{\prime} i$ ve devlet memurlarının \%50,4'ü gerçekleştirdikleri günlerde evde veya kafede bir araya gelmemektedir.

Güne katılan kişilerin cinsiyetleri ile günde tercih ettikleri ödeme yolu arasındaki ilişkiyi belirlemeye yönelik yapılan ki-kare ilişsi testi sonucuna göre, güne katılan kişilerin cinsiyetleri ile tercih ettikleri ödeme yolu arasında anlamlı bir ilişki bulunmaktadır $\left(X^{2}(1)=8,530, p=0,001\right)$. Erkeklerin banka aracllığıla ödeme yolunu tercih etme oranı kadınlardan fazla iken, kadınların elden ödeme yolunu tercih etme oranının erkeklerden fazla olduğu tespit edilmiştir.

Güne katılan kişilerin cinsiyetleri ile evde (veya kafede) toplanıp toplanmadıkları arasındaki ilişkiyi belirlemeye yönelik yapılan ki-kare ilisşi testi sonucuna göre, güne katılan kişilerin cinsiyetleri ile evde (veya kafede) toplanıp toplanmadıkları arasında anlamlı bir ilişki bulunmaktadır (X2(1)=52,646; $\mathrm{p}=0,000$ ). Buna göre kadınların $\% 78,2$ 'si erkeklerin ise $\% 39,9^{\prime}$ u günlerde evde veya kafede bir araya gelmektedir.

Güne katılan kişilerin eğitim durumları ile günde tercih ettikleri ödeme yolu arasındaki ilişkiyi belirlemeye yönelik yapılan likelihood ratio ilişsi testi sonucuna göre, güne katılan kişilerin eğitim durumları ile tercih ettikleri ödeme yolu arasında anlamlı bir ilişki bulunmaktadır $(\operatorname{LHR}(3)=39,711 ; \mathrm{p}=0,000)$. Genel olarak yorumlamak gerekirse güne katılan kişilerin eğitim seviyesi arttıkça günde ödeme yolu olarak bankaların tercih edilme oranı artmaktadır.

Faktör Analizi ve Güvenirlik

Bu çalıșmada Kahyaoglu ve diğerleri (2016) tarafından günlere katılımı etkileyen faktörleri tespit etmek amacıyla oluşturulan anketten faydalanılmıştır. Ayrıca elde edilen nitel verilerden yola çıkarak günlere katılımı etkileyen dini hassasiyet, güven, yardımlaşma ve dayanışma temaları çerçevesinde sorular ankete eklenerek çalışma yapılmıştır. Bu noktada katılımcıların günlere katılma sebeplerini açıklamak için açımlayıcı faktör analizi tercih edilmiştir. Faktör analizi, katılımcıların belirli bir olguya ilişkin düşüncelerinin birbirini 
tamamlayan farklı sorularla ölçülebilmesini sağlar. Anketin üçüncü kısmındaki güne katılma sebeplerini açıklamaya yönelik sorulan açımlayıcı faktör analizine uygun olup olmadığını belirten Kaiser-Meyer-Olkin ve Barlett testleri sonucunda KMO değeri 0,877 ve Barlett's testi p değeri ise 0,000 elde edilmiştir. Buna göre veri tabanının faktör analizine uygun olduğu görülmektedir.

Tablo 11. Faktör analizi sonuçları

\begin{tabular}{|c|c|c|c|c|c|c|c|c|c|}
\hline & \multicolumn{9}{|c|}{ Rotated Component Matrix } \\
\hline & & & & & Comp & bonent & & & \\
\hline & & 1 & 2 & 3 & 4 & 5 & 6 & 7 & 8 \\
\hline \multirow{5}{*}{$\begin{array}{l}\text { Formel finansal } \\
\text { piyasalardan } \\
\text { faydalanamama }\end{array}$} & Kredi bašvurusunda bankalaıın istediği kriterleri sağlavamadığm için oünler & 0,916 & & & & & & & \\
\hline & Bankalar kedi başvurumu kabul etmediăi için qüne katul|rım. & 0,91 & & & & & & & \\
\hline & $\begin{array}{l}\text { Bankadan kredi aldığında bu krediyi ödeyememekten korktuğum için } \\
\text { oünlere katulıım. }\end{array}$ & 0,881 & & & & & & & \\
\hline & Bankacul|kişlemleri bana kar|ş̧ı geldiği için güne katulıım. & 0,795 & & & & & & & \\
\hline & $\begin{array}{l}\text { Faizli borçlandḡımı da veya faiz geliri elde ettiḡimde çevremden kötü } \\
\text { eleştiriler alaçăımı bildiğim için güne katılıım. }\end{array}$ & 0,614 & & & & & & & \\
\hline \multirow{5}{*}{ Manevi Boyut } & Cevremle vardmlașma ve davanıșmamı geliștirmek için güne katulıım. & & 0,832 & & & & & & \\
\hline & Yardımlașma duygusunu hissetmek için güne katulirm. & & 0,82 & & & & & & \\
\hline & Gün üyelerine güvendiğim için güne katıtırım. & & 0,811 & & & & & & \\
\hline & Islami kurallara uygun olduḡu için güne katılırım. & & 0,717 & & & & & & \\
\hline & 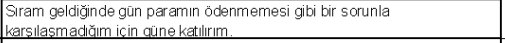 & & 0,641 & & & & & & \\
\hline \multirow{4}{*}{ Sosyalleşme } & Stres atmakve hoșça vakit geçirmek için güne kat|lirm. & & & 0.914 & & & & & \\
\hline & Arkadașlarımla bulușma firsatı sağladığı için güne katulırım. & & & 0,911 & & & & & \\
\hline & Akrabalarımla görüșme firsatı sağladı̆ı̆ için güne katulıım. & & & 0,836 & & & & & \\
\hline & Guncel sorunları değerlendirme firs atı sağladı̆̆ı için güne katilıım. & & & 0,807 & & & & & \\
\hline \multirow{4}{*}{$\begin{array}{l}\text { Aile Bütçesine } \\
\text { Katks }\end{array}$} & Ailemin ortak intivaclarını karșlamak için güne katulirm. & & & & 0,851 & & & & \\
\hline & Ailemin bütçesine kaths sağlamakiçin qüne katlliım. & & & & 0,849 & & & & \\
\hline & Beklenmedik acil nakit ihtivacı için güne katulırm. & & & & 0,636 & & & & \\
\hline & Olası sağllk problemlerinde hullanmakiçin güne katulırm. & & & & 0,585 & & & & \\
\hline \multirow{4}{*}{ Temel Tüketim } & Elektronikeşya ( $T V$, telefon, beyaz eșyavb.) almak için gune katllirım. & & & & & 0,765 & & & \\
\hline & Düğün, nişan ve çeyiz masraflarını karşılamak için güne katulıım. & & & & & 0,677 & & & \\
\hline & GIda malzemesi satin almakiçin güne katulirım. & & & & & 0,653 & & & \\
\hline & Borclarımı (kredi, kredi kartı vb.) ödemekiçin güne katllırm. & & & & & 0,607 & & & \\
\hline \multirow{2}{*}{$\begin{array}{l}\text { Faizden } \\
\text { Kaçınma }\end{array}$} & Faizle borçlanma maliyetine katlanmak istemediğgim için güne katulirm. & & & & & & 0,787 & & \\
\hline & Faiz geliri elde etmek istemediğim için gune katulirm. & & & & & & 0,758 & & \\
\hline \multirow{2}{*}{$\begin{array}{l}\text { Tasarrufa } \\
\text { Zorlama }\end{array}$} & Gereksiz harcamalarımın önüne geçemediğim için güne kaillnm. & & & & & & & 0,805 & \\
\hline & Para biriktirmekte güclük celtiğim için güne katulirm. & & & & & & & 0,804 & \\
\hline \multirow{5}{*}{ Yatırm } & Ev, arsa gibi gayrimenkul al abilmekiçin güne katulırm. & & & & & & & & 0,849 \\
\hline & Araba satin almak için güne katılırm. & & & & & & & & 0,830 \\
\hline & Açılkanan Toplam Varyans & & & & & & & & 76,857 \\
\hline & KMO and Bartlett's Test & & & & & & 0,877 & & 0.000 \\
\hline & Cronbach Alpha (Gene, 0.912) & 0.910 & 1.878 & 0.903 & 1862 & 0.777 & 0.895 & 0.789 & 0.915 \\
\hline
\end{tabular}

Açımlayıcı faktör analizi sonucunda sorular 8 faktör altında toplanmıştır ve bu faktörlerin açılkladığı toplam varyans \%76,857'dir. Ölçekteki faktörlerin madde yük değerleri 0,585 ile 0,916 arasında değişmektedir. Ölçeğin güvenirliğini belirten Cronbach Alpha değeri 0,912'dir. Faktörlerin altında yer alan maddeler incelerek eğilimleri kapsayan faktörler şu şekilde adlandırıldı: Formel finansal piyasalardan faydalanamama $(0,910)$, manevi boyut $(0,878)$, sosyalleşme $(0,903)$, aile bütçesine katkı $(0,862)$, temel tüketim $(0,777)$, faizden kaçınma $(0,895)$, tasarrufa zorlama $(0,789)$ ve yatırım $(0,915)$.

Kahyaoğlu vd.'nin (2016) uyguladıkları ankete, nitel bulgulardan elde edilen ve 2 pilot çalışmada tespit edilen yardımlaşma, dayanışma, güven ve dini hassasiyet sorularının eklenmesi ve bunların Manevi Boyut faktörünün altında toplanması, çalışmanın özgünlüğünü oluşturan hususlardan biridir. Karma yöntem çalışmalarının temel amacını oluşturan nitelden elde edilen bulguların nicelle genele uygulanması ve desteklenmesi noktasında günlere katılımı etkileyen sebeplerden birinin de günün manevi boyutu olduğu tespit edilmiştir. 
Güne katılmayı etkileyen faktörlerin cinsiyet, eğitim düzeyi ve mesleklere göre nasıl farklılaştığını analiz etmek amacıyla parametrik olmayan Mann-Whitney $U$ ve Kruskall Wallis testleri uygulanmıştır. Parametrik olmayan testlerin uygulanmasının nedeni, 5'li likert sorularına verilen cevapların normallik varsayımını sağlamamasıdır.

Tablo 12. Mann-whitney u testi sonuçları

\begin{tabular}{|c|c|c|c|c|c|c|c|}
\hline Faktörler & Gruplar & $\mathbf{N}$ & Ortalama & Ortc. & $\begin{array}{l}\text { Siralar } \\
\text { Ort. }\end{array}$ & $\mathbf{U}$ & $\mathbf{P}$ \\
\hline \multirow{2}{*}{$\begin{array}{l}\text { Formel Finansal } \\
\text { Piyasalardan Fay- } \\
\text { dalanamama }\end{array}$} & Erkek & 138 & 2,0681 & 1,9 & 197,19 & \multirow{2}{*}{11,497} & \multirow{2}{*}{0,001} \\
\hline & Kadın & 211 & 1,728 & 1,2 & 160,49 & & \\
\hline \multirow{2}{*}{ Sosyalleşme } & Erkek & 138 & 2,5707 & 2,75 & 121,43 & \multirow{2}{*}{12,771} & \multirow{2}{*}{0,000} \\
\hline & Kadın & 211 & 3,6825 & 4 & 210,04 & & \\
\hline \multirow{2}{*}{ Temel Tüketim } & Erkek & 138 & 2,5362 & 2,75 & 189,24 & \multirow{2}{*}{12,593} & \multirow{2}{*}{0,032} \\
\hline & Kadın & 211 & 2,3128 & 2,53 & 165,68 & & \\
\hline \multirow{2}{*}{ Faizden Kaçınma } & Erkek & 138 & 3,471 & 4,00 & 203,97 & \multirow{2}{*}{10,561} & \multirow{2}{*}{0,000} \\
\hline & Kadın & 211 & 2,7133 & 3,00 & 156,05 & & \\
\hline \multirow{2}{*}{ Yatırım } & Erkek & 138 & 2,7283 & 3,00 & 194,12 & \multirow{2}{*}{11,921} & \multirow{2}{*}{0,003} \\
\hline & Kadın & 211 & 2,3294 & 2,00 & 162,5 & & \\
\hline \multirow{2}{*}{ Manevi Boyut } & Erkek & 138 & 3,7580 & 4,00 & 187,95 & \multirow{2}{*}{12,771} & \multirow{2}{*}{0,052} \\
\hline & Kadın & 211 & 3,4464 & 3,60 & 166,53 & & \\
\hline \multirow{2}{*}{$\begin{array}{l}\text { Aile Bütçesine } \\
\text { Katkı }\end{array}$} & Erkek & 138 & 3,0274 & 3,25 & 178,29 & \multirow{2}{*}{13,934} & \multirow{2}{*}{0,570} \\
\hline & Kadın & 211 & 2,9123 & 3,00 & 172,04 & & \\
\hline \multirow{2}{*}{ Tasarrufa Zorlama } & Erkek & 138 & 3,4674 & 4,00 & 181,26 & \multirow{2}{*}{13,694} & \multirow{2}{*}{0,342} \\
\hline & Kadın & 211 & 3,2844 & 3,50 & 170,9 & & \\
\hline
\end{tabular}

Katılımcıların cinsiyetleri ile güne katılmayı etkileyen faktör ortalamalarında anlamlı farklılık olup olmadığına bakıldığında, formel finansal piyasalardan faydalanamama, sosyalleşme, temel tüketim, faizden kaçınma ve yatırım faktörlerinde anlamlı farklllık olduğu tespit edilmiștir. Buna göre formel finansal piyasalardan faydalanamama faktöründe Kahyaoglu vd. (2016, s. 249) bulgularının tersine erkeklerin ortalamalarının kadınlardan daha yüksek olduğu görülmektedir.

İkinci olarak, kadınların sosyalleşme faktörü ortalamasının erkeklerden daha fazla olduğu tespit edilmiştir. Kadınların boş zaman etkinliklerinden biri olarak görülen günlerin, kadınlar arasında sosyal kültürel hatta psikolojik etkileri olduğu vurgulanmıștır (Büyükokutan, 2012; Karayiğit, 2015). Ayrıca kadınların sosyal ilişki ağlarının erkeklerden daha güçlü olması sebebiyle güne katıldıklarını belirtilmiştir (Levenson ve Besley, 1996, s. 52).

Üçüncü olarak, temel tüketim faktörü ortalaması erkeklerde kadınlardan daha fazladır. Türkiye'de erkeklerin iş gücüne katılım oranının daha yüksek 
olması ve ailenin geçiminin erkekler tarafından üstlenilmesi, erkeklerin temel tüketim faktörü ortalamasının daha yüksek olmasını açıklamaktadır.

Dördüncü olarak, faizden kaçınma faktörü ortalamasının erkeklerde kadınlardan daha yüksek olduğu tespit edilmiștir.

Son olarak, yatırım faktörü ortalamasının erkeklerde kadınlardan daha fazla olduğu tespit edilmiştir. Yatırım faktörünü oluşturan sorular çerçevesinde bakıldığında Türkiye'de konut alım satımında ve sürücü sayısında erkeklerin sayısının daha fazla olması bu ortalamanın farklılığını açıklamaktadır (TÜíK, 2020).

Tablo 13. Eğitim düzeylerine göre faktör ortalamaları farklarını gösteren kruskal wallis $(\mathrm{kw})$ testi sonuçları

\begin{tabular}{|c|c|c|c|c|c|c|c|}
\hline Faktörler & $\begin{array}{l}\text { Eğitim } \\
\text { Durumu }\end{array}$ & $\mathbf{N}$ & Ortalama & Ortanca & $\mathrm{H}$ & p & Anlamlı Fark \\
\hline \multirow{5}{*}{$\begin{array}{c}\text { Formel Finansal } \\
\text { Piyasalardan } \\
\text { Faydalanamama }\end{array}$} & Lise ve altı & 103 & 2,1282 & 2,00 & \multirow{5}{*}{11,817} & \multirow{5}{*}{0,008} & \multirow{5}{*}{$\begin{array}{l}\text { Lisansüstü - lise ve altı (p: } \\
\qquad 0,009)\end{array}$} \\
\hline & Önlisans & 41 & 1,7366 & 1,20 & & & \\
\hline & Lisans & 134 & 1,8224 & 1,60 & & & \\
\hline & Lisansüstü & 71 & 1,6254 & 1,20 & & & \\
\hline & Toplam & 349 & 1,8625 & 1,60 & & & \\
\hline \multirow{5}{*}{ Sosyalleşme } & Lise ve altı & 103 & 3,4490 & 3,50 & \multirow{5}{*}{10,56} & \multirow{5}{*}{0,014} & \multirow{5}{*}{$\begin{array}{l}\text { Lisansüstü - Lisans (p: 0,042); } \\
\text { Lisansüstü - Lise ve altı (p: } \\
\text { 0,017) }\end{array}$} \\
\hline & Önlisans & 41 & 3,3963 & 3,50 & & & \\
\hline & Lisans & 134 & 3,2873 & 3,50 & & & \\
\hline & Lisansüstü & 71 & 2,7711 & 3,00 & & & \\
\hline & Toplam & 349 & 3,2428 & 3,50 & & & \\
\hline \multirow{5}{*}{$\begin{array}{l}\text { Aile Bütçesine } \\
\text { Katkl }\end{array}$} & Lise ve altı & 103 & 3,3568 & 3,50 & \multirow{5}{*}{19,349} & \multirow{5}{*}{0,000} & \multirow{5}{*}{$\begin{array}{l}\text { Lisansüstü - Lise ve altı (p: } \\
0,001 \text { ); Lisans - Lise ve altı } \\
\text { (p: } 0,001 \text { ) }\end{array}$} \\
\hline & Önlisans & 41 & 3,0375 & 3,50 & & & \\
\hline & Lisans & 134 & 2,7780 & 2,75 & & & \\
\hline & Lisansüstü & 71 & 2,6725 & 2,75 & & & \\
\hline & Toplam & 349 & 2,9576 & 3,25 & & & \\
\hline \multirow{5}{*}{ Temel Tüketim } & Lise ve altı & 103 & 2,6869 & 2,75 & \multirow{5}{*}{14,627} & \multirow{5}{*}{0,002} & \multirow{5}{*}{$\begin{array}{l}\text { Lisansüstü - Lise ve altı (p: } \\
0,002 \text { ); Lisans - Lise ve altı } \\
\text { (p: } 0,027 \text { ) }\end{array}$} \\
\hline & Önlisans & 41 & 2,3720 & 2,00 & & & \\
\hline & Lisans & 134 & 2,3284 & 2,25 & & & \\
\hline & Lisansüstü & 71 & 2,1408 & 2,00 & & & \\
\hline & Toplam & 349 & 2,4011 & 2,50 & & & \\
\hline
\end{tabular}




\begin{tabular}{|c|c|c|c|c|c|c|c|}
\hline \multirow{5}{*}{ Manevi Boyut } & Lise ve altı & 103 & 3,7126 & 4,00 & \multirow{5}{*}{3,032} & \multirow{5}{*}{0,387} & \multirow{5}{*}{ - } \\
\hline & Önlisans & 41 & 3,4000 & 3,40 & & & \\
\hline & Lisans & 134 & 3,5642 & 3,90 & & & \\
\hline & Lisansüstü & 71 & 3,4704 & 3,60 & & & \\
\hline & Toplam & 349 & 3,5696 & 3,80 & & & \\
\hline \multirow{5}{*}{ Faizden kaçınma } & Lise ve altı & 103 & 2,9709 & 3,00 & \multirow{5}{*}{3,655} & \multirow{5}{*}{0,301} & \multirow{5}{*}{ - } \\
\hline & Önlisans & 41 & 2,8049 & 2,50 & & & \\
\hline & Lisans & 134 & 2,9701 & 3,00 & & & \\
\hline & Lisansüstü & 71 & 3,2746 & 3,50 & & & \\
\hline & Toplam & 349 & 3,0129 & 3,00 & & & \\
\hline \multirow{5}{*}{$\begin{array}{c}\text { Tasarrufa } \\
\text { Zorlama }\end{array}$} & Lise ve altı & 103 & 3,3107 & 3,50 & \multirow{5}{*}{3,89} & \multirow{5}{*}{0,274} & \multirow{5}{*}{ - } \\
\hline & Önlisans & 41 & 3,4634 & 4,00 & & & \\
\hline & Lisans & 134 & 3,4739 & 4,00 & & & \\
\hline & Lisansüstü & 71 & 3,1408 & 3,50 & & & \\
\hline & Toplam & 349 & 3,3567 & 3,50 & & & \\
\hline \multirow{5}{*}{ Yatırım } & Lise ve altı & 103 & 2,5243 & 2,50 & \multirow{5}{*}{2,962} & \multirow{5}{*}{0,397} & \multirow{5}{*}{ - } \\
\hline & Önlisans & 41 & 2,5976 & 2,50 & & & \\
\hline & Lisans & 134 & 2,3545 & 2,00 & & & \\
\hline & Lisansüstü & 71 & 2,6197 & 2,50 & & & \\
\hline & Toplam & 349 & 2,4871 & 2,00 & & & \\
\hline
\end{tabular}

Katılımcıların eğitim düzeyi ile faktör ortalamalarında anlamlı farklılık olup olmadı̆̆ına bakıldığında, formel finansal piyasalardan faydalanamama faktöründe lisansüstü - lise ve altı eğitim düzeyleri arasında, sosyalleşme faktöründe lisansüstü - lisans ve lisansüstü - lise ve altı eğitim düzeyleri arasında, temel tüketim faktöründe ise lisansüstü - lise ve altı ve lisans - lise ve altı eğitim düzeyleri arasında anlamlı farklılık olduğu tespit edilmiștir. Buna göre formel finansal piyasalardan faydalanamama faktöründe lise ve altı eğitim düzeyine sahip katılımcıların ortalaması lisansüstü eğitim düzeyine sahip katılımcıların ortalamasından daha yüksektir. Eğitim düzeyi lise ve altı olan katılımclların, formel finansal piyasalardan faydalanma noktasında yaşadıkları sorunlar dolayısıyla finansman ihtiyaçlarının bir kısmını günlerden sağladığı sonucu çıkarılabilir. Alternatif olarak günlerin işleyiş ve katılım sağlama noktasında basit, anlaşılır bir yapıya sahip olmasının, eğitim düzeyi daha düşük olan kişilerin güne katılmasında etki sahibi olduğu söylenebilir.

Sosyalleşme faktörüne bakıldığında lisansüstü eğitim düzeyine sahip katılımcıların ortalaması lisans ve lise ve altı eğitim düzeylerinde daha düşüktür. Lisanüstü eğitim düzeyine sahip katılımcıların günlere sosyalleşme amacıyla katılımı diğer eğitim düzeylerine göre daha sınırlı bir etkiye sahiptir. Kahyaoğu vd.'de belirtildiği gibi daha yüksek eğitim seviyesine sahip olan bireyler, 
günleri çocuklarının eğitim harcamalarını karşılamak gibi finansal bir araç olup görmekte ve günlere sosyalleşme değil daha çok ekonomik nedenlerle katılmaktadır.

Aile bütçesine katkı faktöründe ise lise ve altı eğitim düzeyine sahip katılımcıların ortalaması lisans ve lisansüstü katılımcıların ortalamasından yüksektir. Ayrıca temel tüketim faktöründe lise ve altı eğitim düzeyine sahip katılımclların ortalaması lisans ve lisansüstü katılımcıların ortalamasından yüksektir. Bireylerin eğitim düzeyi ile gelir arasındaki pozitif ilişki düşünüldüğünde lise ve altı eğitim düzeyine sahip kişilerin aile bütçelerine katkı sağlamak ve temel tüketimlerini gerçekleştirmek amacıyla günlere katılması günlerin ihtiyaç giderme noktasındaki önemini göstermektedir.

Tablo 14. Mesleklere göre faktör ortalamaları farklarını gösteren KW testi sonuçları

\begin{tabular}{|c|c|c|c|c|c|c|c|c|}
\hline Faktör & Meslek & $\mathrm{N}$ & Ortalama & Ortanca & H & p & sd & Anlamlı Fark \\
\hline \multirow{7}{*}{ Sosyalleşme } & $\begin{array}{c}\text { Ev } \\
\text { Hanımı }\end{array}$ & 76 & 3,8289 & 4,00 & \multirow{7}{*}{33,587} & \multirow{7}{*}{0,000} & \multirow{7}{*}{5} & \multirow{7}{*}{$\begin{array}{l}\text { Serbest Meslek } \\
\text { - Ev Hanımı (p: } \\
0,000) \text {; Devlet } \\
\text { Memuru - Ev } \\
\text { Hanımı (p: } \\
0,000 \text { ) }\end{array}$} \\
\hline & $\begin{array}{l}\text { Serbest } \\
\text { Meslek }\end{array}$ & 49 & 2,8776 & 2,50 & & & & \\
\hline & $\begin{array}{c}\text { Devlet } \\
\text { Memuru }\end{array}$ & 113 & 2,8982 & 3,25 & & & & \\
\hline & İşsiz & 27 & 3,3796 & 4,00 & & & & \\
\hline & İşçi & 63 & 3,2341 & 3,50 & & & & \\
\hline & Öğrenci & 21 & 3,6786 & 4,00 & & & & \\
\hline & Toplam & 349 & 3,2428 & 3,50 & & & & \\
\hline \multirow{7}{*}{ Faizden Kaçınma } & $\begin{array}{c}\text { Ev } \\
\text { Hanımı }\end{array}$ & 76 & 2,7895 & 3,00 & \multirow{7}{*}{18,190} & \multirow{7}{*}{0,003} & \multirow{7}{*}{5} & \multirow{7}{*}{$\begin{array}{l}\text { İşsiz - Devlet } \\
\text { Memuru (p: } \\
\text { 0,006); İşsiz - } \\
\text { Serbest Meslek } \\
\text { (p: 0,011); } \\
\text { İşsiz - İşçi } \\
\text { (p:0,003) }\end{array}$} \\
\hline & $\begin{array}{l}\text { Serbest } \\
\text { Meslek }\end{array}$ & 49 & 3,2347 & 4,00 & & & & \\
\hline & $\begin{array}{l}\text { Devlet } \\
\text { Memuru }\end{array}$ & 113 & 3,1106 & 3,50 & & & & \\
\hline & İşsiz & 27 & 2,0000 & 1,00 & & & & \\
\hline & İşçi & 63 & 3,2937 & 4,00 & & & & \\
\hline & Öğrenci & 21 & 3,2381 & 3,50 & & & & \\
\hline & Toplam & 349 & 3,0129 & 3,00 & & & & \\
\hline
\end{tabular}


Tablo 14. Mesleklere göre faktör ortalamaları farklarını gösteren KW testi sonuçları (devamı)

\begin{tabular}{|c|c|c|c|c|c|c|c|c|}
\hline \multirow{7}{*}{ Tüketim } & Ev Hanımı & 76 & 2,3586 & 2,13 & \multirow{7}{*}{16,612} & \multirow{7}{*}{0,005} & \multirow{7}{*}{5} & \multirow{7}{*}{ - } \\
\hline & $\begin{array}{l}\text { Serbest } \\
\text { Meslek }\end{array}$ & 49 & 2,6429 & 3,00 & & & & \\
\hline & $\begin{array}{c}\text { Devlet } \\
\text { Memuru }\end{array}$ & 113 & 2,2102 & 2,00 & & & & \\
\hline & İşsiz & 27 & 2,0556 & 2,00 & & & & \\
\hline & İşçi & 63 & 2,6310 & 3,00 & & & & \\
\hline & Öğrenci & 21 & 2,7738 & 3,00 & & & & \\
\hline & Toplam & 349 & 2,4011 & 2,50 & & & & \\
\hline \multirow{7}{*}{$\begin{array}{c}\text { Aile Bütçesine } \\
\text { Katkı }\end{array}$} & Ev Hanımı & 76 & 3,1447 & 3,38 & \multirow{7}{*}{11,499} & \multirow{7}{*}{0,042} & \multirow{7}{*}{5} & \multirow{7}{*}{-} \\
\hline & $\begin{array}{l}\text { Serbest } \\
\text { Meslek }\end{array}$ & 49 & 3,2041 & 3,50 & & & & \\
\hline & $\begin{array}{c}\text { Devlet } \\
\text { Memuru }\end{array}$ & 112 & 2,7299 & 2,75 & & & & \\
\hline & İşsiz & 27 & 2,5463 & 2,50 & & & & \\
\hline & İşçi & 63 & 3,1111 & 3,25 & & & & \\
\hline & Öğrenci & 21 & 2,9881 & 3,00 & & & & \\
\hline & Toplam & 348 & 2,9576 & 3,25 & & & & \\
\hline \multirow{7}{*}{$\begin{array}{c}\text { Formel Finansal } \\
\text { Piyasalardan Fay- } \\
\text { dalanamama }\end{array}$} & Ev Hanımı & 76 & 1,8684 & 1,50 & \multirow{7}{*}{6,097} & \multirow{7}{*}{0,297} & \multirow{7}{*}{5} & \multirow{7}{*}{ - } \\
\hline & $\begin{array}{l}\text { Serbest } \\
\text { Meslek }\end{array}$ & 49 & 2,0531 & 2,00 & & & & \\
\hline & $\begin{array}{c}\text { Devlet } \\
\text { Memuru }\end{array}$ & 113 & 1,7611 & 1,40 & & & & \\
\hline & İşsiz & 27 & 1,6000 & 1,40 & & & & \\
\hline & İşçi & 63 & 1,9968 & 1,60 & & & & \\
\hline & Öğrenci & 21 & 1,8762 & 1,60 & & & & \\
\hline & Toplam & 349 & 1,8625 & 1,60 & & & & \\
\hline \multirow{7}{*}{ Manevi Boyut } & Ev Hanımı & 76 & 3,5395 & 3,90 & \multirow{7}{*}{5,113} & \multirow{7}{*}{0,402} & \multirow{7}{*}{5} & \\
\hline & $\begin{array}{l}\text { Serbest } \\
\text { Meslek }\end{array}$ & 49 & 3,7429 & 4,20 & & & & \\
\hline & $\begin{array}{c}\text { Devlet } \\
\text { Memuru }\end{array}$ & 113 & 3,5044 & 3,80 & & & & \\
\hline & İşsiz & 27 & 3,2889 & 3,40 & & & & - \\
\hline & İşçi & 63 & 3,6349 & 3,80 & & & & \\
\hline & Öğrenci & 21 & 3,7905 & 4,20 & & & & \\
\hline & Toplam & 349 & 3,5696 & 3,80 & & & & \\
\hline
\end{tabular}


Tablo 14. Mesleklere göre faktör ortalamaları farklarını gösteren KW testi sonuçları (devamı)

\begin{tabular}{|c|c|c|c|c|c|c|c|c|}
\hline \multirow{7}{*}{$\begin{array}{l}\text { Tasarrufa } \\
\text { Zorlama }\end{array}$} & Ev Hanımı & 76 & 3,2368 & 3,50 & \multirow{7}{*}{6,130} & \multirow{7}{*}{0,294} & \multirow{7}{*}{5} & \multirow{7}{*}{ - } \\
\hline & $\begin{array}{l}\text { Serbest } \\
\text { Meslek }\end{array}$ & 49 & 3,7755 & 4,00 & & & & \\
\hline & $\begin{array}{c}\text { Devlet } \\
\text { Memuru }\end{array}$ & 113 & 3,2566 & 3,50 & & & & \\
\hline & İşsiz & 27 & 3,2222 & 3,50 & & & & \\
\hline & İşçi & 63 & 3,3810 & 3,50 & & & & \\
\hline & Öğrenci & 21 & 3,4524 & 3,50 & & & & \\
\hline & Toplam & 349 & 3,3567 & 3,50 & & & & \\
\hline \multirow{7}{*}{ Yatırım } & Ev Hanımı & 76 & 2,3750 & 2,00 & \multirow{7}{*}{5,564} & \multirow{7}{*}{0,351} & \multirow{7}{*}{5} & \multirow{7}{*}{ - } \\
\hline & $\begin{array}{l}\text { Serbest } \\
\text { Meslek }\end{array}$ & 49 & 2,4796 & 2,00 & & & & \\
\hline & $\begin{array}{c}\text { Devlet } \\
\text { Memuru }\end{array}$ & 113 & 2,5044 & 2,00 & & & & \\
\hline & İşsiz & 27 & 2,1852 & 2,00 & & & & \\
\hline & İşçi & 63 & 2,7857 & 3,00 & & & & \\
\hline & Öğrenci & 21 & 2,3095 & 2,00 & & & & \\
\hline & Toplam & 349 & 2,4871 & 2,00 & & & & \\
\hline
\end{tabular}

Katılımcıların meslekleri ile faktör ortalamalarında anlamlı farklılık olup olmadığına bakıldığında, sosyalleşme faktöründe ev hanımları ile devlet memuru ve serbest meslek sahipleri arasında, faizden kaçınma faktöründe ise işsizler ile devlet memuru ve işçiler arasında anlamlı farklılık olduğu tespit edilmiştir. Buna göre ev hanımlarının sosyalleşme faktörü ortalamaları, serbest meslek ve devlet memurlarından oldukça yüksektir. Literatürde kadınların boş zaman aktivitelerinden biri olarak görülen günlerin (Eroğlu, 2010, s. 476), ev hanımları için sosyalleşme faktörünün diğer meslek gruplarına göre daha fazla öne çıktı̆̆ı görülmektedir. Faizden kaçınma faktörüne bakıldığında işsiz olan katılımcıların ortalamaları, devlet memuru ve işçilere göre daha düşüktür. İşsizlerin, işi ve geliri olanlara göre daha fazla finansmana ihtiyaç duymaları, ekonomik bir yük olsa dahi geçimlerini sağlamak amacıyla faizli borçlanmalarına sebep olabilir. Devlet memurları, işçiler veya serbest meslek sahibi bireyler, geçimlerini sağlamak üzere elde ettikleri gelirlerin yanında faizden kaçınmak amacıyla tasarruflarını günlerde kullanabilme imkânına sahiptir. 
Tablo 15. Katılımcların hanelerinin aylık gelir düzeyi ile faktör ortalamaları arasındaki farklılıkları gösteren KW testi sonuçları

\begin{tabular}{|c|c|c|c|c|c|c|c|}
\hline Faktörler & $\begin{array}{c}\text { Hane Aylık Gelir } \\
\text { Düzeyi }\end{array}$ & $\mathbf{N}$ & $\begin{array}{c}\text { Ortala- } \\
\text { ma }\end{array}$ & Ortanca & H & p & $\begin{array}{l}\text { Anlamlı } \\
\text { Fark }\end{array}$ \\
\hline \multirow{5}{*}{$\begin{array}{l}\text { Formel Finansal } \\
\text { Piyasalardan } \\
\text { Faydalanamama }\end{array}$} & $0-2500 \mathrm{TL}$ & 25 & 1,9840 & 1,40 & \multirow{5}{*}{9,209} & \multirow{5}{*}{0,027} & \multirow{5}{*}{$\begin{array}{c}(2501 \mathrm{TL} \\
-5000 \mathrm{TL}) \\
\text { ve }(7501 \\
\text { TL ve } \\
\text { üstü) (p: } \\
0,038)\end{array}$} \\
\hline & $2501 \mathrm{TL}-5000 \mathrm{TL}$ & 140 & 1,9629 & 1,80 & & & \\
\hline & $5001 \mathrm{TL}-7500 \mathrm{TL}$ & 75 & 1,9653 & 1,80 & & & \\
\hline & 7501 TL ve üstü & 109 & 1,6349 & 1,00 & & & \\
\hline & Toplam & 349 & 1,8625 & 1,60 & & & \\
\hline \multirow{5}{*}{$\begin{array}{l}\text { Aile Bütçesine } \\
\text { Katkı }\end{array}$} & $0-2500 \mathrm{TL}$ & 25 & 3,4800 & 4,00 & \multirow{5}{*}{15,925} & \multirow{5}{*}{0,001} & \multirow{5}{*}{$\begin{array}{c}(2501- \\
5000 \mathrm{TL}) \\
\text { ve }(7501 \\
\text { TL ve } \\
\text { üstü) (p: } \\
0,010) ;(0 \\
2500 \mathrm{TL}) \\
\text { ve }(7501 \\
\text { TL ve } \\
\text { üstü) (p: } \\
0,005)\end{array}$} \\
\hline & $2501 \mathrm{TL}-5000 \mathrm{TL}$ & 140 & 3,1295 & 3,25 & & & \\
\hline & $5001 \mathrm{TL}-7500 \mathrm{TL}$ & 75 & 2,9367 & 3,25 & & & \\
\hline & 7501 TL ve üstü & 109 & 2,6330 & 2,50 & & & \\
\hline & Toplam & 349 & 2,9576 & 3,25 & & & \\
\hline
\end{tabular}

Tablo 15. Katılımcıların hanelerinin aylık gelir düzeyi ile faktör ortalamaları arasındaki farklılıkları gösteren KW testi sonuçları (devamı)

\begin{tabular}{|c|c|c|c|c|c|c|c|}
\hline \multirow{5}{*}{ Temel Tüketim } & $0-2500 \mathrm{TL}$ & 25 & 2,6800 & 2,75 & \multirow{5}{*}{10,594} & \multirow{5}{*}{0,014} & \multirow{5}{*}{$\begin{array}{c}(2501 \mathrm{TL} \\
-5000 \mathrm{TL}) \\
\text { ve (7501 } \\
\text { TL ve üstü) } \\
\text { (p: } 0,017)\end{array}$} \\
\hline & $2501 \mathrm{TL}-5000 \mathrm{TL}$ & 140 & 2,5464 & 2,50 & & & \\
\hline & $5001 \mathrm{TL}-7500 \mathrm{TL}$ & 75 & 2,3667 & 2,25 & & & \\
\hline & 7501 TL ve üstü & 109 & 2,1743 & 2,00 & & & \\
\hline & Toplam & 349 & 2,4011 & 2,50 & & & \\
\hline \multirow{5}{*}{ Manevi Boyut } & $0-2500 \mathrm{TL}$ & 25 & 3,6560 & 3,80 & \multirow{5}{*}{1,61} & \multirow{5}{*}{0,657} & \multirow{5}{*}{ - } \\
\hline & $2501 \mathrm{TL}-5000 \mathrm{TL}$ & 140 & 3,6414 & 4,00 & & & \\
\hline & $5001 \mathrm{TL}-7500 \mathrm{TL}$ & 75 & 3,5973 & 4,00 & & & \\
\hline & 7501 TL ve üstü & 109 & 3,4385 & 3,60 & & & \\
\hline & Toplam & 349 & 3,5696 & 3,80 & & & \\
\hline \multirow{5}{*}{ Sosyalleşme } & $0-2500 \mathrm{TL}$ & 25 & 3,3900 & 4,00 & \multirow{5}{*}{2,446} & \multirow{5}{*}{0,485} & \multirow{5}{*}{ - } \\
\hline & $2501 \mathrm{TL}-5000 \mathrm{TL}$ & 140 & 3,2714 & 3,50 & & & \\
\hline & $5001 \mathrm{TL}-7500 \mathrm{TL}$ & 75 & 3,3500 & 3,50 & & & \\
\hline & 7501 TL ve üstü & 109 & 3,0986 & 3,25 & & & \\
\hline & Toplam & 349 & 3,2428 & 3,50 & & & \\
\hline
\end{tabular}




\begin{tabular}{|c|c|c|c|c|c|c|c|}
\hline \multirow{5}{*}{ Faizden kaçınma } & $0-2500 \mathrm{TL}$ & 25 & 2,8400 & 3,00 & \multirow{5}{*}{2,29} & \multirow{5}{*}{0,514} & \multirow{5}{*}{ - } \\
\hline & $2501 \mathrm{TL}-5000 \mathrm{TL}$ & 140 & 3,0750 & 3,00 & & & \\
\hline & $5001 \mathrm{TL}-7500 \mathrm{TL}$ & 75 & 3,1400 & 3,50 & & & \\
\hline & 7501 TL ve üstü & 109 & 2,8853 & 3,00 & & & \\
\hline & Toplam & 349 & 3,0129 & 3,00 & & & \\
\hline \multirow{5}{*}{ Tasarrufa Zorlama } & $0-2500 \mathrm{TL}$ & 25 & 3,3200 & 4,00 & \multirow{5}{*}{0,342} & \multirow{5}{*}{0,952} & \multirow{5}{*}{. } \\
\hline & $2501 \mathrm{TL}-5000 \mathrm{TL}$ & 140 & 3,4393 & 3,50 & & & \\
\hline & $5001 \mathrm{TL}-7500 \mathrm{TL}$ & 75 & 3,3133 & 3,50 & & & \\
\hline & 7501 TL ve üstü & 109 & 3,2890 & 4,00 & & & \\
\hline & Toplam & 349 & 3,3567 & 3,50 & & & \\
\hline \multirow{5}{*}{ Yatırım } & $0-2500 \mathrm{TL}$ & 25 & 2,5600 & 2,50 & \multirow{5}{*}{0,213} & \multirow{5}{*}{0,975} & \multirow{5}{*}{ - } \\
\hline & 2501 TL -5000 TL & 140 & 2,4821 & 2,00 & & & \\
\hline & 5001 TL - 7500 TL & 75 & 2,4933 & 2,00 & & & \\
\hline & 7501 TL ve üstü & 109 & 2,4725 & 2,50 & & & \\
\hline & Toplam & 349 & 2,4871 & 2,00 & & & \\
\hline
\end{tabular}

Katılımcıların hanelerinin aylık gelirleri ile faktör ortalamalarında anlamlı farklılık olup olmadığına bakıldığında, formel finansal piyasalara ulaşamama faktöründe 2501 TL-5000 TLaylık geliri olanlar ile 7501 TL ve üstü aylık geliri olanlar arasında, aile bütçesine katkı faktöründe ise $2501 \mathrm{TL}-5000 \mathrm{TL}$ aylık geliri olanlar ile 7501 TL ve üstü aylık geliri olanlar ve 0-2500 TL aylık geliri olanlar ile $7501 \mathrm{TL}$ ve üstü aylık geliri olanlar arasında anlamlı farklılık olduğu tespit edilmiştir. Son olarak temel tüketim faktöründe 2501 TL-5000 TL aylık geliri olanlar ile 7501 TL ve üstü aylık geliri olanlar arasında anlamlı farklılık olduğu tespit edilmiştir. Buna göre 2501 TL-5000 TL aylıklı geliri olanların formel finansal piyasalardan faydalanamama faktörü ortalamaları 7501 TL ve üstü aylık geliri olanlara göre daha yüksektir. Geliri daha düşük olan bireylerin özellikle bankalar tarafından talep edilen kriterleri sağlayamaması veya borç aldığında geri ödeyememe korkusu, onları günlere yönlendirmektedir. Çünkü bireyler günlere katılırken genellikle kendileriyle benzer gelir düzeyindeki kişileri tercih etmektedir (Stefan Ambec ve Treich, 2007, s. 130).

Aile bütçesine katkı faktörüne bakıldığında 0-2500 TL ve 2501-5000 TL aylık geliri olanların bu faktördeki ortalamalarının 7501 TL ve üstü aylık geliri olanlara göre ortalamaları daha yüksektir. Daha düşük gelir düzeylerinde günlerin ihtiyaç giderme işlevinin ön plana çıtı̆ğı görülmektedir (Eroğlu, 2010, s. 475). Bunun bir diğer göstergesi, 2501 TL-5000 TL aylık geliri olanların 7501 TL ve üstü aylık geliri olanlara göre temel tüketim faktörü ortalamalarının daha yüksek olmasıdır. 


\section{Sonuç ve Tartışma}

İslam iktisadı alanında daha çok bankacılık üzerinde yapılan çalışmalar, banka haricindeki alternatiflerin geri planda tutulmasına sebep olmaktadır. Finansal kapitalizmin İslam iktisadı üzerindeki etkisi olarak görülen bu durumun aşılması adına alternatif finansman yollarına odaklanılması gerekmektedir. Bunun en önemli sebeplerinden biri, anonim finansal işlemlerin ötesinde karşılıklı yardımlaşma ve dayanışma ile finansman sağlanabilecek yolların olmasıdır. Bireyselliğin uç noktalarında olunan bir dönemde bu alternatiflerin değeri daha da artmaktadır. Bu çalışmada da günlerin alternatif finansman yollarından biri olarak dayanışma ve yardımlaşma temelinde pek çok işlevi olduğu ortaya koyulmaktadır.

Günler birçok toplumda görülen ve Türkiye'de her kesimden bireyin katıldığı bir fenomen olarak karşımıza çıkmaktadır. Gün olgusunun bireylerin çevresiyle güven temelinde kurulan bir ilişki olması, sosyal teminatlar üzerinden iktisadi işlevini görmesi söz konusudur. Çalışmanın nitel kısmında da ortaya çıkan güven, dayanışma ve dini hassasiyet temaları, nicel kısımda, manevi boyut faktörünün altında toplanmaktadır. Gün fenomeni toplumda alışılagelmiş bir şekilde uygulanırken bireylerin, birlikte güne katıldıkları kişilerin "hakkını" korumaya, onlarla "helalleşmeye" dikkat etmesi, günlerin İslami açıdan uygun olduğunun düşünülmesi, sıla-i rahim konusunda bireylere imkân tanıması, manevi boyutun derinliğini göstermektedir. Nicel bölümde bu açıların kısmi olarak ortaya koyulduğu görülse de karma yöntemin avantajlarından yararlanarak nitel kısımdan elde edilen daha geniş perspektifteki bulgular bu noktayı desteklemektedir. Çalışma boyunca banka dışı yapılar içerisinde ele alınan günler, finansman işlevinin sosyali göz ardı etmeden gerçekleştirmenin bir yolu olarak, iktisadın sosyale gömülü olan (embedded) yerini tekrardan hatırlatmaktadır.

Günlerin sosyalleşme boyutu kadınlar için daha çok öne çıkmaktadır. Ayrıca sadece kadınlar için değil erkekler için de önem taşıyan günlerin bu özelliği, Graeber'in bahsettiği "insani sosyal ekonomileri" akla getirmektedir. Bireylerin yakın çevresindekilerle hem sosyal hem iktisadi bir ilişki olarak günlere katılması, finansal bir ihtiyaç durumunda anonim ilişkilerden uzak bir bağ kurularak bu ihtiyacın giderilmesi imkânını sunmaktadır.

Günlerin iktisadi boyuttaki en önemli yönü, düşük gelir gruplarının aile bütçelerine katkı yapması ve temel tüketimlerini gerçekleştirmelerini sağlamasıdır. İkinci olarak, dini hassasiyet, kredi işlemlerinde bürokrasi, karmaşıklık veya kredibil olmama gibi gerekçelerle formel finansal piyasalara erişememe durumlarında, bireylerin finansmana erişimleri hususunda günler önemli bir iktisadi rol üstlenmektedir.

Türkiye'de sayıları artan TDFFS yapılarının yaptıkları faaliyeti açılarken "tıpkı altın günlerindeki" ifadesini kullanması, günlerin toplum tarafından bilinen bir uygulama olmasından dolayıdır. TDFFS yapıları günlerin ticari 
açıdan gelişmiş ve sistemleşmiş bir türüdür. Bu açıdan günlerin önemli bir sosyal finansman potansiyeli taşıdığını söylemek gereklidir. Bununla birlikte düşünüldüğünde İslami finans literatüründe çok kısıtlı bir alanda kalan gün fenomeni üzerine daha fazla çalışma yapılması gerektiği belirtilmelidir. Türkiye'de katılım bankalarının toplum tarafından İslamiliğinin hala tartışılıyor olması, kendilerini iyi ifade edemediklerinin bir göstergesidir. Bu açıdan toplum ve toplumsal ilişkilerle bağları kuvvetli finansal kuruluşlar kurulabilmesi için, toplumun uzun yıllar deneyimlediği, faydaları ve zararlarıyla aşina olduğu yapıların özelliklerini tespit etmek gerekmektedir. Bu kapsamda gün fenomeninden yola çıkılarak modern sosyal finans enstrümanların toplumun ekonomik kalkınmasında önemli bir rolü olacağını söylemek mümkündür. Toplum temelli yapılara bir örnek olan günlerin, önce grup içi sonrasında ise yarı-kurumsal ve kurumsal yapılar ile kalkınmada aktif rol alabileceklerdir.

Günlerin dini açıdan faiz hassasiyeti sebebiyle bankalara karşı olan bireyler için alternatif bir finansman yolu olduğu da görülmektedir. Bu çalışmayla, bireylerin hayat görüşlerinin iktisadi ve sosyal davranışları etkilemesinde ve farklı organizasyon yapılarının oluşmasında etkili olduğu görülmekte ve ileriki çalışmalar için bu tarz toplum temelli yapıların araştırılmasının toplumsal kabulü yüksek olan kurumların inşasında önemli bir rol oynayacağı düşünülmektedir.

\section{Kaynakça}

Aksak, E. ve Asutay, M. (2011). Does Islamic Finance Make the World Economically and Financially Safer? Islamic Finance and Its Implications on Sustainable Economic Growth. 8th International Conference on Islamic Economics and Finance.

Aliero, I. H. (2014). An Analytical Review on The Concept, Financial Practices and Shari'ah Compatibility Of Rotating Saving And Credit Associations (ROSCAs). Journal of Islamic Economics, 10(4), 129.

Ambec, S. ve Treich, N. (2003). Roscas as financial agreements to cope with social pressure. Centre for Studies in Economics and Finance (C. 103). http://scholar.google. $\mathrm{com} / \mathrm{scholar}$ hl=en\&btnG=Search\&q=intitle:Roscas+as+financial+agreements+to+cope+with+social+pressure\# 0 adresinden erişildi.

Ambec, Stefan ve Treich, N. (2007). Roscas as financial agreements to cope with self-control problems. Journal of Development Economics, 82(1), 120-137. doi:10.1016/j.jdeveco.2005.09.005

Apaydın, H. Y. (2001). Karz. Türkiye Diyanet Vakfı İslâm Ansiklopedisi. Ankara: TDV Yayınları.

Ardener, S. (1964). The Comparative Study of Rotating Credit Associations. The Journal of the Royal Anthropological Institute of Great Britain and Ireland, 94(2), 201-229. doi:10.2307/2844382 
Aredo, D. (2004). Rotating Savings And Credit Associations: Characterization With Particular Reference To The Ethiopian Iqqub. Savings and Development, 28(2), 179-200. https://about.jstor.org/terms adresinden erişildi.

Asutay, M. (2012). Conceptualising and Locating the Social Failure of Islamic Finance: Aspirations of Islamic Moral Economy vs the Realities of Islamic Finance. Asian and African area studies, 11(2), 93-113.

Beck, T., Demirgüç-Kunt, A. ve Merrouche, O. (2013). Islamic vs. Conventional Banking: Business Model, Efficiency and Stability. Journal of Banking and Finance, 37(2), 433-447. doi:10.1016/j.jbankfin.2012.09.016

Besley, T., Coate, S. ve Loury, G. (1993). The Economics of Rotating Savings and Credit Associations. The American Economic Review, 83(4), 792-810.

Büyükokutan, A. (2012). Geleneksel Altın Günlerine Halkbilimsel Bir Yaklaşım: "Muğla Örneği". Karadeniz Uluslararası Bilimsel Dergi, (14), 117-133.

Chong, S. B. ve Liu, M.-H. (2009). Islamic banking Interest-free or interest-based.pdf. Pacific-Basin Finance Journal, 125-144.

Creswell, J. W. (2017a). Karma Yöntem Araștırmalarına Giriş. (M. Sözbilir, Çev.). Ankara: Pegem Akademi.

Creswell, J. W. (2017b). Araştırma Deseni-Nitel, Nicel ve Karma Yöntem Yaklaşımları. (S. B. Demir, Çev.). Ankara: Eğiten Kitap.

Creswell, J. W. (2019). Eğitim Araştırmaları. (H. Ekşi, Çev.). Istanbul: EDAM.

Dekle, R. ve Hamada, K. (2000). On the Development of Rotating Credit Associations in Japan. Economic Development and Cultural Change, 49(1), 77-90. doi:10.1037//1082-989X.5.2

Duman, S. (2018). Günümüz Fıkıh Problemleri. (O. Güman, Ed.). İstanbul: Beka Yayıncllık.

Durmuş, A. (2010). Fıkıhta Karz (Ödünç) Sözleșmesinde Vade Şartının Bağlayıcılığı Meselesi. İslam Hukuku Araştırmaları Dergisi, (16), 315-330.

El- Ashker, A. ve Wilson, R. (2019). İslam İktisadının Kısa Tarihi. İstanbul: İktisat Yayinları.

Eminevim. (2020). Merak Edilenler. 26 Nisan 2020 tarihinde https://www.eminevim. $\mathrm{com} /$ merak-edilenler adresinden erișildi.

Eroğlu, Ș. (2010). Informal finance and the urban poor: An investigation of rotating savings and credit associations in Turkey. Journal of Social Policy, 39(3), 461-481. doi:10.1017/S0047279409990699

Gan, P.-T. (2010). Optimal Monetary Policy for Malaysia: Islamic Rule versus Conventional Rule. Review of Islamic Economics, 14(2), 47-68.

Geertz, C. (1962). The Rotating Credit Association: A "Middle Rung" in Development. Source: Economic Development and Cultural Change, 10(3), 241-263.

Graeber, D. (2015). Borç İlk 5000 Yll. (M. Pehlivan, Çev.) (1. bs.). İstanbul: Everest.

Gugerty, M. K. (2007). You Cant Save Alone Commitment in Rotating Saving and Credit Associations in Kenya. Economic Development and Cultural Change, 55(2), 251282. 
Harper, M. (1994). Musharaka partnership financing - an approach to venture capital for microenterprise. Small Enterprise Development, 5(4), 27-36. doi:10.3362/09571329.1994.037

Hassan, A. ve Harahap, S. S. (2010). Exploring corporate social responsibility disclosure: the case of Islamic banks. International Journal of Islamic and Middle Eastern Finance and Management, 3(3), 203-227.

Kahyaoglu, M. B., Alpay, E. E. ve Yavuz, M. (2016). Why People Participate Rosca? New Evidence From Turkey. Journal of Business, Economics and Finance, 5(2), 242-257.

Karayiğit, E. (2015). Gendered Fields in Women's Leisure Time Experiences: The Case of "Gün" meetings in Ankara. http://etd.lib.metu.edu.tr/upload/12618731/index.pdf adresinden erişildi.

Kaya, S. (2019). Flkıh Konusunda Bilinmesi Gereken 88 Soru. (O. Güman ve S. Duman, Ed.). İstanbul: Beyan Yayınları.

Khan, F. (2010). How "Islamic" is Islamic Banking? Journal of Economic Behavior and Organization. doi:10.1016/j.jebo.2010.09.015

Kirton, C. (1996). Rotating Savings and Credit Associations in Jamaica: Some Empirical Findigs on Partner. Social and Economic Studies, 45(2), 195-224.

Levenson, A. R. ve Besley, T. (1996). The anatomy of an informal financial market: Rosca participation in Taiwan. Journal of Development Economics, 51(1), 45-68. doi:10.1016/S0304-3878(96)00425-7

Neuman, W. L. (2014). Toplumsal Araştırma Yöntemleri. (S. Özge, Çev.). Ankara: Siyasal Kitabevi.

Pollard, J. ve Samers, M. (2007). Islamic Banking and Finance: Postcolonial Political Economy and the Decentring of Economic Geography. Transactions of the Institute of British Geographers. doi:10.4337/9781843765318

Sadr, S. K. (2017). The optimum size of rotating qarḍ hasan savings and credit associations. ISRA International Journal of Islamic Finance, 9(1), 15-26. doi:10.1108/ IJIF-07-2017-003

Tchuindjo, L. (1999). The Evolution Of An Informal Financial Institution: The Rotating Savings And Credit Associatıon In Cameroon. African Review of Money Finance and Banking, 5-20. http://www.jstor.org/stable/23026369 adresinden erişildi.

Türkiye İstatistik Kurumu. (2020). Konut İstatistikleri. 20 Mart 2020 tarihinde http:// www.tuik.gov.tr/PreTablo.do?alt_id=1056 adresinden erişildi.

Ullah, M. S., Naimi, N. Bin ve Yusoff, R. B. M. (2016). The Impact of Entrepreneurs' Levels of Education, Age and Years in Business on Their Decision to Obtain Finance for Small and Medium Enterprises (SMES) From Rotating Savings and Credit Associations (ROSCAS) in Lahore. The Social Sciences, 11(13), 3252-3256. doi:10.3923/ sscience.2016.3252.3256 